\title{
Construction Safety Program for the National Ignition Facility
}

June 26, 1997

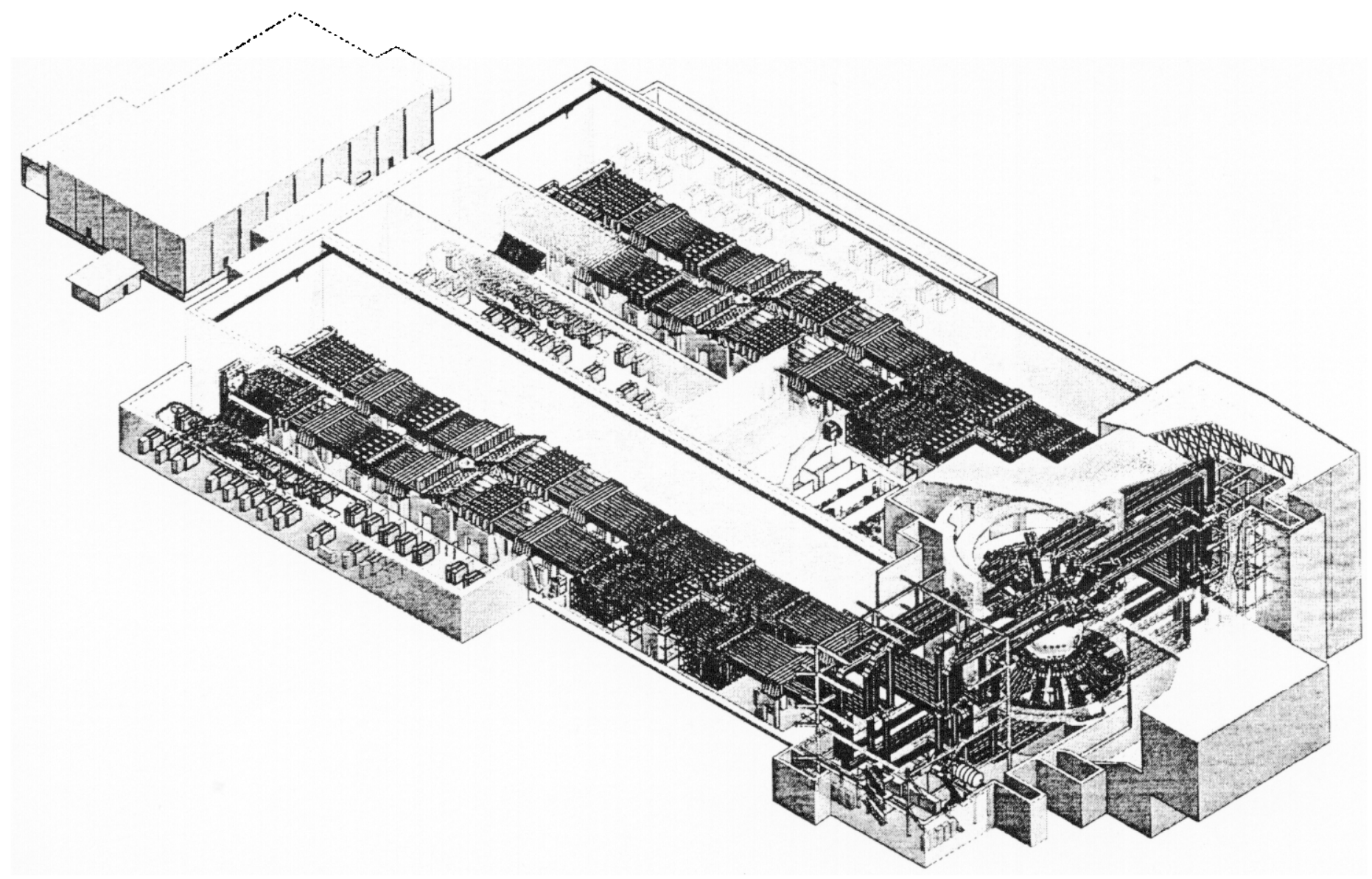




\section{DISCLAIMER}

This document was prepared as an account of work sponsored by an agency of the United States Government. Neither the United States Government nor the University of California nor any of their employees, makes any warranty, express or implied, or assumes any legal liability or responsibility for the accuracy, completeness, or usefulness of any information, apparatus, product, or process disclosed, or represents that its use would not infringe privately owned rights. Reference herein to any specific commercial product, process, or service by trade name, trademark, manufacturer, or otherwise, does not necessarily constitute or imply its endorsement, recommendation, or favoring by the United States Government or the University of California. The views and opinions of authors expressed herein do not necessarily state or reflect those of the United States Government or the University of California, and shall not be used for advertising or product endorsement purposes.

This report has been reproduced directly from the best available copy.

Available to DOE and DOE contractors from the Office of Scientific and Technical Information

P.O. Box 62, Oak Ridge, TN 37831

Prices available from (615) 576-8401, FTS 626-8401

Available to the public from the

National Technical Information Service

U.S. Department of Commerce

5285 Port Royal Rd.,

Springfield, VA 22161 


\title{
Construction Safety Program for the National Ignition Facility
}

\author{
Steven J. Cerruti
}

June 26, 1997 
NIF-0001321

UCRL-ID-125990 Rev. 1 


\section{Construction Safety Program for the National Ignition Facility}

\section{Safety and Health Policy for the National Ignition Facility During Construction}

The National Ignition Facility Project at Lawrence Livermore National Laboratory (LLNL) is committed to providing protection for NIF workers, LLNL site-wide workers and the public from hazards associated with the construction and operation of the National Ignition Facility (NIF), and for providing a safe, healthful and secure work environment for all persons directly involved with NIF.

All work related to NIF construction and parallel operations during the construction period will be performed in a manner that protects the health and safety of NIF workers, LLNL site-wide workers and the public, preserves the quality of the environment, and prevents property damage. Safety, health and environment are to be priority considerations in the planning and execution of work related to NIF. Furthermore, the NIF Project at LLNL will comply with all applicable Safety, Health and Environmental laws, regulations, and requirements.

In addition, LLNL, Lasers Program and NIF Management are committed to insist that comprehensive safety and health rules and procedures are established and enforced during the construction period of NIF, whenever practical, and used to achieve the NIF Project goal objective of ZERO accidents.

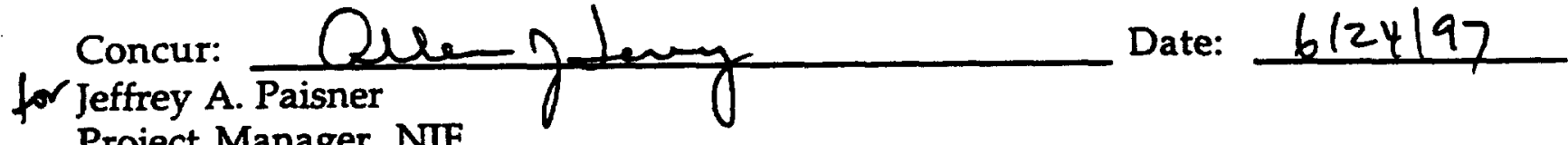
Project Manager, NIF

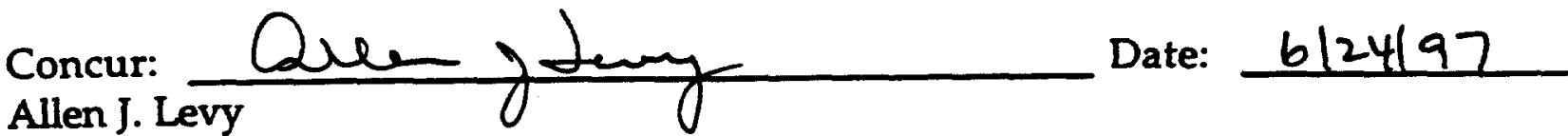
Acting Associate Project Engineer for Conventional Facilities, NIF

Concur:

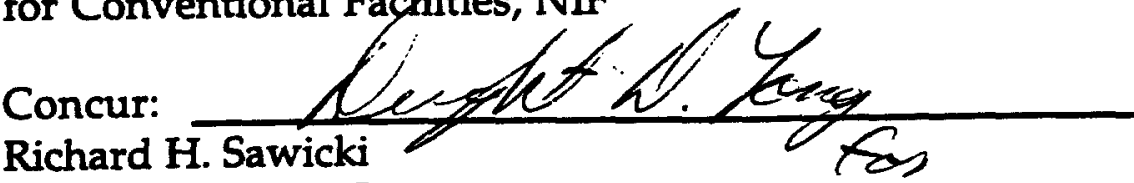

Date:

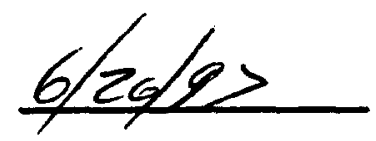
Associate Project Engineer for Special Equipment, NIF 
NIF-0001321

NIF Construction Safety Program

concur: Cunt A.Clant

Date: $6 / 26 / 97$

Curtis A. Cower

Associate Project Engineer

for Activation and Start-Up, NIF

Concur:

Date: $6 / 25 / 97$

Jon M. Yatabe

Assurance Manager, NIF

concur: Olitilleumbtatcher

Date: $6-2 y-97$

C. William Hatcher

Assurance Manager,

Lasers Program Directorate

concur: Helhect S Kew

Date: $6 / 23 / 97$

Michael G. Trent

Division Leader,

ES\&H Team 2

ii 


\section{Contents}

Safety and Health Policy for the National Ignition ........................................................... i

List of Acronyms ........................................................................................................................... vi

Preface ............................................................................................................................................

NIF ES\&H document hierarchy ................................................................................................ ix

Introduction ......................................................................................................................... 1

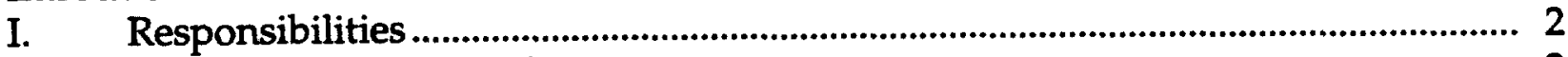

I.A. NIF Project Office ......................................................................................... 2

I.A.1. Project Manager..................................................................................... 2

I.A.2. Assurance Manager ........................................................................ 3

I.A.3. Associate Project Engineer for Conventional Facilities .............. 3

I.A.4. Associate Project Engineer for Special Equipment ..................... 4

I.A.5. Associate Project Engineer for Activation and Start-up............. 4

I.A.6. Deputy Associate Project Engineer for Construction .................. 5

I.A.7. Construction Manager for Conventional Facilities ....................... 6

I.A.8. Special Equipment (SE) Construction Managers.......................... 8

I.A.9. System Engineers ............................................................................10

I.A.10. Safety Coordinator............................................................................ 10

I.A.11. Construction Safety Officers.............................................................. 10

I.A.12. Construction Inspectors .................................................................... 11

I.A.13. LLNL Employees................................................................................. 12

I.A.14. Non-LLNL Employees (Excluding NIF Construction

Contractors and Subcontractors) ..................................................... 12

I.B. NIF Construction Contractors and Subcontractors...................................... 13

I.C. Lasers Program Assurance Office..................................................................16

I.D. LLNL Hazards Control Department ...............................................................17

I.D.1. Environment, Safety, and Health Team 2..................................... 17

I.D.2. Emergency Management Division .................................................. 18

I.E. Risk Management Office .................................................................................. 18

I.F. Owner Controlled Insurance Program (OCIP) for NIF's

Conventional Facilities ......................................................................................... 19

I.G. Project Safety Team .......................................................................................20

I.H. NIF Safety Organization Chart..................................................................... 21

II. Stop-Work Authority and Procedures .................................................................... 22

II.A. Imminent Danger Situations.......................................................................22

II.B. Other Situations...................................................................................................22

II.C. Differences of Opinion................................................................................22

II.D. Resumption of Work..............................................................................2

III. Accident/Incidents ...............................................................................................2 24

III.A. Emergency Assistance Procedures ............................................................. 24

III.B. Self-Help Plan .................................................................................................. 24

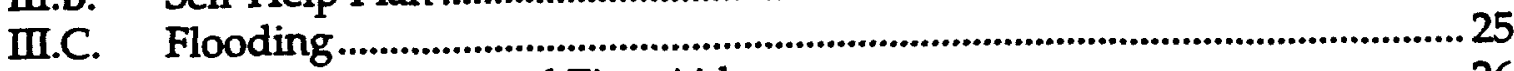

III.D. Medical Services and First Aid........................................................................... 26 
III.D.1 Health Services Availability 27

III.E. Reporting and Investigation Procedures ....................................................2

III.E.1. Policy and Scope......................................................................... 27

III.E.2. Purpose.......................................................................................... 28

III.E.3. Occupational Injuries/Illnesses Notification

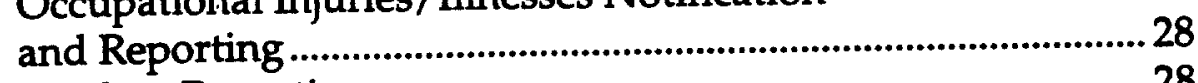

III.E.4. Incident Reporting ...................................................................... 28

III.E.5. DOE Occurrence Reporting Requirements ..................................28

III.E.6. Investigation Procedures.................................................................. 29

III.E.7. Injury Report Retention.................................................................... 30

III.F. Privacy Notification ...

III.G. Sample NIF Accident/Incident Investigation Form.....................................32

IV. Drug Free Workplace Program ..................................................................................3 35

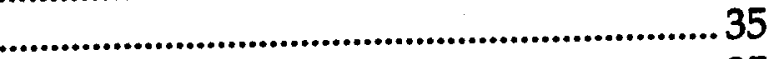

IV.B. NIF Drug Free Workplace Policy Overview ................................................35

IV.C. Requirements for NIF Construction Contractors/Subcontractors.............35

IV.C.1. Substance Testing Program................................................................. 35

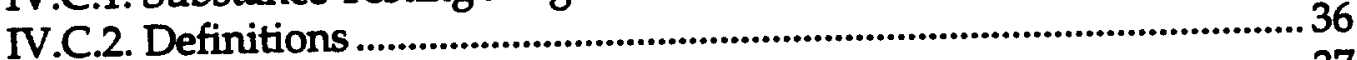

V. Pre-Phase Planning-Job Hazard Analysis (JHA)..................................................37

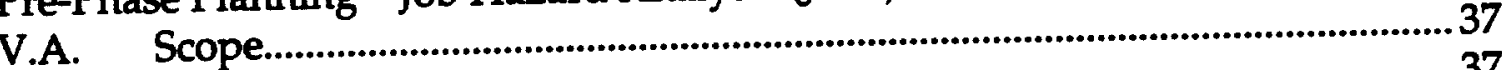

.

.

.

V.D. Construction Activities

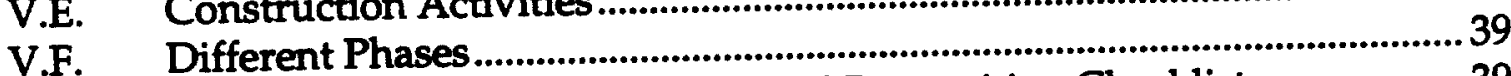

V.G. Pre-Job Safety Planning and Hazard Recognition Checklist .......................39

V.G.1. Establish project safety policy................................................................39

V.G.2. Planning for safety................................................................................40

V.G.3. Mitigation of property damage ..........................................................40 40

VIraining

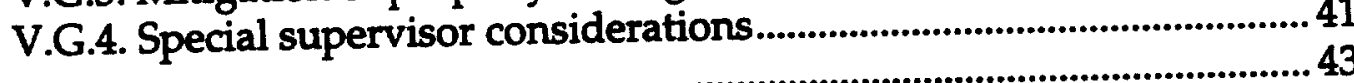

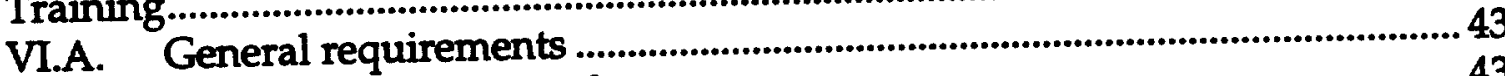

VI.A.1. Bulletin Board................................................................................. 43

VI.A.2. Safety Meetings .................................................................................. 43

VI.A.3. First-Aid Stations................................................................................ 43

VI.B. Guidelines for Safety Training Meetings ........................................................43

VI.B.1. Weekly Basis $\ldots$

VI.B.2. Essential Element ................................................................................44

VI.B.3. Guidelines .................................................................................... 44

VI.B.4. Record Keeping Requirements......................................................... 45

VII. Safety Award Program .......................................................................................47

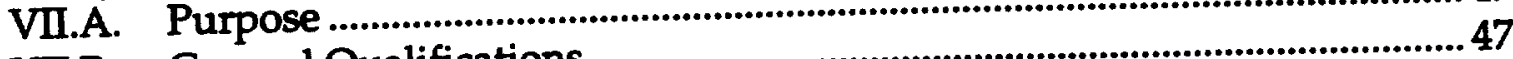

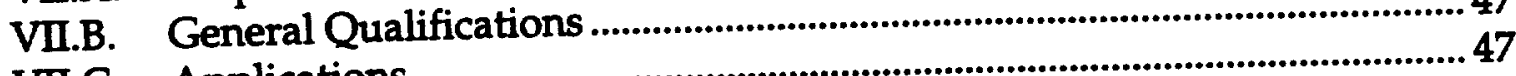

VII.C. Applications 
VII.D. Award Presentations.........................................................................................48

VII.E. Eligibility.......................................................................................................4 49

VIII. NIF Project Health \& Safety Plans ..............................................................................5

VIII.A. Requirement........................................................................................................50

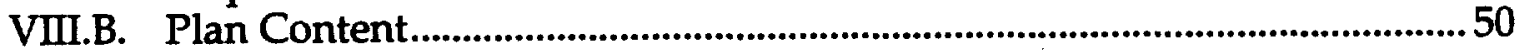

VIII.C. Plan Acceptance.................................................................................................50 


\section{List of Acronyms}

$\begin{array}{ll}\text { ANSI } & \text { American National Standards Institute } \\ \text { APL } & \text { assembly point leader } \\ \text { CAL/OSHA } & \text { California Occupational Safety and Health Administration } \\ \text { CBSC } & \text { California Building Standards Code } \\ \text { CCR } & \text { California Code of Regulations } \\ \text { CFR } & \text { Code of Federal Regulations } \\ \text { CHP } & \text { California Highway Patrol } \\ \text { CII } & \text { Construction Industry Institute } \\ \text { CSO } & \text { Construction Safety Officer } \\ \text { CSP } & \text { Construction Safety Program for the NIF } \\ \text { DefTrack } & \text { Laser Programs Directorate's ES\&H deficiency tracking database } \\ \text { DOE } & \text { Department of Energy } \\ \text { DOT } & \text { Department of Transportation } \\ \text { EMC } & \text { Emergency Management Center } \\ \text { EMD } & \text { Emergency Management Division (of HCD) } \\ \text { EPA } & \text { Environmental Protection Agency } \\ \text { EPD } & \text { LLNL's Environmental Protection Department } \\ \text { ES\&H } & \text { environment, safety, and health } \\ \text { FHA } & \text { Fire Hazards Analysis } \\ \text { FSAR } & \text { Final Safety Analysis Report } \\ \text { FSP } & \text { Facility Safety Procedure } \\ \text { GISO } & \text { General Industry Safety Order } \\ \text { GFCI } & \text { Ground fault circuit interrupter } \\ \text { HCD } & \text { LLNL's Hazards Control Department } \\ \text { HCS } & \text { Hazard Communication Standard } \\ \text { HSD } & \text { LLNL's Health Services Department } \\ \text { HWM } & \text { LLNL's Hazardous Waste Management division } \\ \text { ICD } & \text { interface control document } \\ \text { IIPP } & \text { Injury and Ilness Prevention Program } \\ \text { JHA } & \text { Job Hazards Analysis } \\ \text { LLIX } & \text { LLNL Telephone Exchange } \\ \text { LLNL } & \text { Lawrence Livermore National Laboratory } \\ \text { MAP } & \text { Mitigation Action Plan } \\ \text { MSDS } & \text { material safety data sheet } \\ \text { NEPA } & \text { National Environmental Policy Act } \\ \text { NFPA } & \text { National Fire Protection Association } \\ \text { NIF } & \text { National Ignition Facility } \\ \text { NRR } & \text { Noise Reduction Rating } \\ \text { OAB } & \text { Optics Assembly Building } \\ \text { OCIP } & \text { Owner Controlled Insurance Program } \\ \text { ORR } & \text { Operational Readiness Review } \\ \text { OSHA } & \text { Occupational Safety and Health Administration } \\ & \end{array}$


OSP

OSR

OTP

Operational Safety Procedure

PEIS

PHA

PPE Operational Safety Requirement

Operational Test Procedures

Programmatic Environmental Impact Statement

Preliminary Hazards Analysis

PSAR

Personnel protective equipment

QA

Preliminary Safety Analysis Report

ROD

quality assurance

SAAR

Record of Decision

SAR

Supervisor's Accident Analysis Report

SARA

SDR

SE Safety Analysis Report

Superfund Amendments and Reauthorization Act

SHP

SLO

SWPPP

UC

System Design Requirement

Special Equipment

Self-Help Program

supplemental labor only

Storm Water Pollution Prevention Plan

University of California 


\section{Preface}

This Construction Safety Program document fits into the NIF Environment, Safety, and Health (ES\&H) document hierarchy in the following way (see figure next page). The NIF ESEH Management Plan is the top-level management document for environmental and occupational safety and health matters. It carries out the LLNL Health and Safety Manual and the applicable DOE Orders and Federal and state regulations (e.g., 10CFR835). The environmental documents that are developed (i.e., flow down) from the NIF ESEH Management Plan include the Programmatic Environmental Impact Statement (PEIS), Record of Decision (ROD), Mitigation Action Plan (MAP), and the environmental permits. The occupational safety and health documents developed from the NIF ES\&H Management Plan include the Preliminary Hazards Analysis (PHA), Preliminary Safety Analysis Report (PSAR), Construction Safety Program (this document), and (Construction) Health and Safety Plans for individual Elements of NIF.

The final operational safety document is the Final Safety Analysis Report (FSAR), which is implemented by the Facility Safety Procedure, Operational Safety Requirements, and Operational Safety Procedures. 


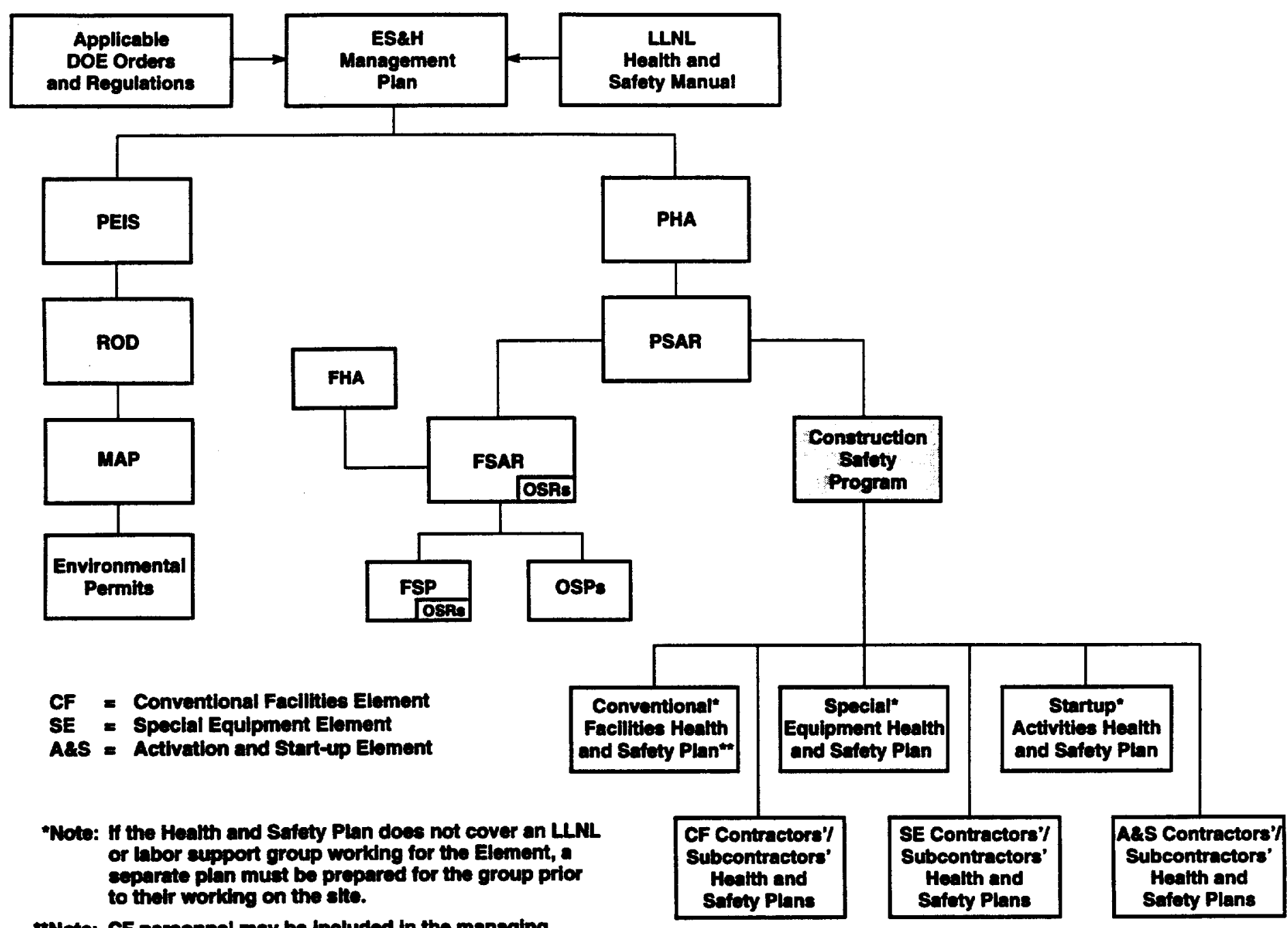

*Note: CF personnel may be included in the managing construction contractor's Haalth and Safety Plan.

\section{conersteces}

nambo

NIF ES\&H document hierarchy. 


\section{Introduction}

The Construction Safety Program (CSP) for NIF sets forth the responsibilities, guidelines, rules, policies and regulations for all workers involved in the construction, special equipment installation, acceptance testing, and initial activation and operation of NIF at LLNL during the construction period of NIF. During this period, all workers are required to implement measures to create a universal awareness which promotes safe practice at the work site, and which will achieve NIF's management objectives in preventing accidents and illnesses. Construction safety for NIF is predicated on everyone performing their jobs in a manner which prevents job-related disabling injuries and illnesses.

The CSP outlines the minimum environment, safety, and health (ES\&H) standards, LLNL policies and the Construction Industry Institute (CII) Zero Injury Techniques requirements that all workers at the NIF construction site shall adhere to during the construction period of NIF. It identifies the safety requirements which the NIF organizational Elements (i.e., Conventional Facilities, Special Equipment, Activation and Start-up), construction contractors and construction subcontractors must include in their safety plans for the construction period of NIF, and presents safety protocols and guidelines which workers shall follow to assure a safe and healthful work environment. However, the CSP does not cover the full spectrum of published safety, health and environmental standards which are mandated by law, the University of California's (UC) contract with the U.S. Department of Energy (DOE) for operating LLNL, and the Programmatic Environmental Impact Statement for Stockpile Stewardship and Management. As such, NIF Elements, construction contractors and construction subcontractors should not assume that they are only responsible for those standards which are referenced in the CSP or that those standards are current and quoted as published. Construction contractors and construction subcontractors who feel that their safety practices exceed current California and Federal OSHA standards, LLNL policies and CII Zero Injury Techniques requirements may provide a copy of their safety procedures to NIF Project Management for review and approval.

The CSP also identifies the ES\&H responsibilities of LLNL employees, non-LLNL employees, construction contractors, construction subcontractors, and various levels of management within the NIF Program at LLNL. In addition, the CSP contains the responsibilities and functions of ES\&H support organizations and administrative groups, and describes their interactions with the NIF Program. 


\section{Responsibilities}

It is the responsibility of all workers at the NIF construction site to perform work safely and in accordance with all LLNL policies as well the CSP. Workers at the site are accountable for their own safety and the safety of others who could be impacted by their activities. Certain organizations and workers performing supervisory roles have specified responsibilities for carrying out safety-related activities. Workers who perform supervisory functions have increased safety obligations. Management and supervisory workers may delegate safety authority to others in their line organizations; however, the accountability for safety performance and assurance is not transferable.

The responsibilities identified below primarily pertain to safety-related responsibilities of the individual(s), organization or firm during the construction of NIF. The individual(s), organization, or firm may have additional responsibilities which are unrelated to safety during construction of NIF or inadvertently omitted, and hence not mentioned. However, omission of such responsibilities does not preclude the individual(s), organization, or firm from fulfilling their responsibilities.

\section{I.A. NIF Project Office}

\section{I.A.1. Project Manager}

The Project Manager, supported by the Principal Deputy Project Manager from LLNL, has the overall contractor authority and responsibility for the execution of the NIF Project. Responsibilities include:

- Conduct NIF Project work in accordance with the applicable federal and state regulations, DOE Orders, and institutional standards, requirements, and procedures, as they pertain to ES\&H issues.

- Work through the Assurance Manager to ensure that environmental, safety, radiation protection, quality assurance, and security programs are established and maintained to meet applicable federal, state, and local regulatory requirements.

- Plan and implement the construction, equipment procurement and installation by working with the Associate Project Engineers for Conventional Facilities, Special Equipment and Activation and Start-Up.

- Provide adequate funding for administering the CSP for NIF.

- Concur with the CSP for NIF. 


\section{I.A.2. Assurance Manager}

The Assurance Manager is responsible for the oversight of ES\&H, quality, and security aspects of the NIF Project. He reports directly to the Project Manager. Responsibilities include:

- Approve the CSP for NIF and ensure that it is carried out.

- Perform safety analyses of NIF construction and operation: Preliminary Hazards Analysis (PHA), Preliminary Safety Analysis Report (PSAR), and Final Safety Analysis Report (FSAR) with Operational Safety Requirements (OSRs).

- Obtain the NEPA determination and the environmental permits related to construction.

- Prepare and ensure implementation of the ES\&H Management Plan.

- Develop the environmental and safety working group to review project ES\&H issues.

- Provide oversight that all applicable federal, state and local ES\&H regulations are followed.

- Interface with the DOE ES\&H Manager and Lasers Program Assurance Office on all assurance issues.

- Oversee the NIF Occurrence and Accident reporting program.

\section{I.A.3. Associate Project Engineer for Conventional Facilities}

The Associate Project Engineer for Conventional Facilities is responsible for the design, procurement, installation, and acceptance testing of the NIF experimental and Optics Assembly Building (OAB) facilities. Responsibilities include:

- Manage and direct the Deputy Associate Project Engineer for Construction.

- Design, construct, inspect, and acceptance test the NIF conventional facilities.

- Ensure that the conventional facilities design and construction meets applicable ES\&H, performance category, Quality Assurance (QA), security, and other regulatory requirements.

- Ensure the construction of NIF is performed in accordance with applicable ES\&H standards.

- Ensure all contractors/subcontractors for Conventional Facilities have adequate Safety Plans.

- Interface with the Associate Project Engineers for Special Equipment and Activation and Start-up.

- Provide adequate funding for administering the safety program for Conventional Facilities and associated contractors/subcontractors.

- Develop and administer the NIF Occurrence and Accident reporting program for all occurrences and accidents occurring at the construction site.

- Concur with the CSP for NIF. 


\section{I.A.4. Associate Project Engineer for Special Equipment}

The Associate Project Engineer for Special Equipment is responsible for the design, procurement, installation, and acceptance testing of the NIF Special Equipment. Responsibilities include:

- Manage and direct the System Engineers for all NIF Special Equipment.

- Manage and direct the Special Equipment Construction Managers (e.g., Laser Construction Manager and Target Area Construction Manager).

- Design, procure, install, and acceptance test all special equipment.

- Ensure that the special equipment design meets applicable ES\&H, performance category, QA, security, and other regulatory requirements.

- Define the special equipment interface input for NIF.

- Ensure the installation of NIF special equipment is performed in accordance with applicable ES\&H standards and the Facilities for NIF.

- Ensure preparation of the Safety Plan for Special Equipment.

- Ensure all contractors/subcontractors for Special Equipment have adequate Safety Plans.

- Interface with the Associate Project Engineers on Conventional Facilities and Activation and Start-up.

- Provide adequate funding for administering safety program for Special Equipment and associated contractors/subcontractors.

- Concur with the CSP for NIF.

\section{I.A.5. Associate Project Engineer for Activation and Start-up}

The Associate Project Engineer for Activation and Start-up is responsible for planning and implementing the activation and start-up of NIF. Responsibilities include:

Plan, staff, and manage the activation and start-up of the NIF.

- Manage and direct the engineers providing System Design Requirements (SDRs), Interface Control Documents (ICDs), Title I, II, and III design, acquisition, and activation of operations support equipment. This includes transport and handling equipment for optics assemblies, as well as cleaning and assembly equipment for the $\mathrm{OAB}$.

- Write the NIF Start-up Plan and implement the key activities, such as staff training and qualification. Work with Assurances to ensure that the activation and start-up meet federal, state, and local regulatory requirements.

- Ensure that the activation activities meet applicable ES\&CH, performance category, QA, security, and other regulatory requirements.

- Ensure the operation of NIF during construction activities is performed in accordance with applicable ES\&H standards. 
- Ensure preparation of the Safety Plan for Activation and Start-up operations if such operations occur during the construction phase of NIF.

- Ensure all contractors/subcontractors for Activation and Start-Up have adequate Safety Plans.

- Confirm that all Activation and Start-up worker safety education and orientation requirements (including applicable environmental orientation) are met.

- Interface with the Associate Project Engineer for Conventional Facilities and the Associate Project Engineer for Special Equipment.

- Prepare and approve the operations and maintenance procedures ensuring that requirements, such as the OSRs (e.g., limits of operation), are incorporated.

- Interface with the DOE on the Operational Readiness Review.

- Provide adequate funding for administering safety program for Activation and Start-Up and associated contractors/subcontractors.

- Concur with the CSP for NIF.

\section{I.A.6. Deputy Associate Project Engineer for Construction}

The Deputy Associate Project Engineer for Construction is responsible for directing the construction of the NIF experimental and OAB facilities and overseeing the occupational safety and health of LLNL employees and non-LLNL employees (associated with the Conventional Facilities Element of NIF). The position reports to the Associate Project Engineer for Conventional Facilities. Some duties (i.e., "responsibilities") may be delegated to other safety personnel; however, accountability for performance of such duties remains with the Deputy Associate Project Engineer for Construction. Responsibilities include:

- Manage and direct the Field Construction Manager for Conventional Facilities, acting as the Contracting Officer's Technical Representative.

- Coordinate the preparation of the Construction Schedule, integrating it with complementary schedules for special equipment.

- Ensure that the required permits (e.g., SWPPP, digging, welding) are in place.

- Oversee the construction, inspection, testing, and acceptance testing of the conventional facilities. Support the Contracting Officer in the bid/award process for construction contractors and subcontractors.

- Ensure that construction contractors/subcontractors have adequate Safety Plans.

- Ensure that the construction contractors/subcontractors are performing all work in accordance with applicable ES\&H standards and the Construction Safety Program for NIF.

- Ensure that the construction, special equipment installation and activation and start-up operations are coordinated and interferences are resolved.

- Document that work-in-place meets all contractual requirements. 
- Develop and manage the Owner Controlled Insurance Program (OCIP) for Conventional Facilities.

- Ensure that all Conventional Facilities personnel are familiar with the OCIP.

\section{I.A.7. Construction Manager for Conventional Facilities}

The Field Construction Manager for Conventional Facilities shall monitor the occupational safety and health of Sverdrup employees, construction contractors and construction subcontractors (associated with the Conventional Facilities Element of NIF) during the construction of the NIF experimental and OAB facilities. The position reports to the Deputy Associate Project Engineer for Construction

Monitoring duties include:

- Monitor the construction activities of the Conventional Facilities Construction Contractors/Subcontractors.

- Perform inspection, testing, and acceptance of the conventional facilities.

- Support the Contracting Officer in the bid/award process for construction contractors and subcontractors.

- Assist the Deputy Associate Project Engineer for Construction with ensuring that the construction, special equipment installation and activation and start-up operations are coordinated and interferences are resolved.

- Develop site specific safety and environmental video presentation and orientation required under OCIP for all necessary personnel.

- Develop and conduct a customized site specific 10-hour OSHA class for all required contractor/subcontractor supervision.

- Verify weekly safety briefings for Conventional Facilities Construction Staff personnel are conducted.

- Conduct daily construction site safety audits, records and compliance reviews in randomly pre-selected areas for Conventional Facility contractors/ subcontractors.

- Act as Element liaison with the Safety Coordinator

- Be a member of the Project Safety Team.

- (Deleted)

- Review the construction contractors'/subcontractors' safety plans for Conventional Facilities.

- Verify that all the construction contractors/subcontractors for Conventional Facilities are performing work in accordance with applicable ES\&H standards.

- Verify that all Conventional Facility worker safety education and orientation requirements (including applicable environmental orientation) are met. 
- Review the results of the Conventional Facility audits for compliance, recommendations made for correction and prevention of recurrence, and followup measures taken to develop compliance.

- Review records of all accidents experienced by Conventional Facility workers.

- Keep Conventional Facility contractors'/subcontractors' safety representatives advised on the adequacy of their safety program.

- Verify that the following safety requirements are met for Conventional Facilities subcontractors:

- Implementation of the procedures outlined in the CII publication "Zero Injury Techniques."

- Implementation of the procedures outlined in the CII publication "Managing Subcontractor Safety"

- Establishment and maintenance of a safe and healthy work environment by adherence to the guidelines and procedures issued in the latest document of the Federal, State, and site specific requirements.

- Implementation to the Substance and Alcohol Abuse Prevention Program.

- All Conventional Facility personnel and contractors/subcontractors implement and abide by ES\&H rules and regulations set forth by all regulatory agencies as well as those identified in the CSP for NIF.

- Work activities are pre-planned in order to identify and control any safety and health issues which may pose a hazard to workers or others.

- Meetings are conducted with NIF Project Management to review accident prevention measures.

- NIF Management are knowledgeable of all contractor/subcontractor safety programs.

- Communications with contractors/subcontractors are maintained.

- CSP general requirements apply to visitors.

- Specific job safety training is completed.

- Safety audits are performed and deficiencies corrected.

- Investigation of all injuries, accidents, and incidents are conducted.

- Safety inspections with Conventional Facilities contractors/subcontractors are reviewed.

- Job hazard analyses are performed.

- Assign and manage Conventional Facilities Construction Management safety personnel.

- Contractor/subcontractor safety records and performance audits are conducted.

- Contractor/subcontractor safety plan is reviewed for adequacy prior to contractor/subcontractor mobilization. 
- Contractor/subcontractor safety meetings are attended by LLNL representatives.

- All necessary contractor/supervisor supervisors attend a customized site specific 10 hour OSHA class for supervision.

- Safe Work Recognition programs are developed by subcontractors.

\section{I.A.8. Special Equipment (SE) Construction Managers}

The Special Equipment (SE) Construction Managers are responsible for overseeing the safety of LLNL employees, non-LLNL employees, construction contractors and construction subcontractors (associated with the Special Equipment Element of NIF) during the construction of the NIF. The position reports to the Associate Project Engineer for Special Equipment. Some duties (i.e., "responsibilities") may be delegated to the Construction Safety Officer upon agreement; however; accountability for performance of such duties remains with the SE Construction Manager. Responsibilities include:

- Support the Contracting Officer in the bid/award process for construction contractors and subcontractors.

- Ensure that the special equipment installation is coordinated with conventional facilities activities and activation and start-up operations, and interferences are resolved.

- Ensure that the LLNL employees, non-LLNL employees, construction contractors and construction subcontractors (associated with the Special Equipment Element) are performing all work in accordance with applicable ES\&H standards and the Facilities for NIF.

- Act as Element liaison with the Safety Coordinator.

- Be a member of the Project Safety Team.

- Ensure development of the Safety Plan for Special Equipment.

- Ensure that construction contractors/subcontractors for Special Equipment have adequate Safety Plans.

- Review construction contractors'/subcontractors' Safety Plans for Special Equipment.

- Confirm all Special Equipment worker safety education and orientation requirements are met.

- Ensure that safety compliance audits are performed and documented.

- Review the results of the Special Equipment audits for compliance, recommendations made for correction and prevention of recurrence, and followup measures taken to ensure compliance.

- Review records of all accidents experienced by Special Equipment workers.

- Keep Special Equipment contractors'/ subcontractors' safety representatives advised on the adequacy of their safety program. 
- Verify that the following safety requirements are met for Special Equipment:

- Establishment and maintenance of a safe and healthy work environment by adherence to the guidelines and procedures issued in the latest document of the Federal, State, and site specific requirements.

- All Special Equipment personnel and contractors/subcontractors implement and abide by the ES\&H rules and regulations set forth by all regulatory agencies as well as those identified in the CSP for NIF.

- Work activities are pre-planned in order to identify and control any safety and health issues which may pose a hazard to workers or others.

- Meetings are conducted with NIF Project Management to develop accident prevention measures.

- NIF Management is knowledgeable of all contractor/subcontractor safety programs.

- Communications with contractors/subcontractors are maintained.

- CSP general requirements apply to visitors.

- Specific job safety training is completed.

- Safety audits are performed and deficiencies corrected.

- Investigation of all injuries, accidents, and incidents are conducted.

- Safety inspections with Special Equipment contractors/subcontractors are reviewed.

- Job hazard analyses are performed.

- Assign and manage site safety personnel.

- Contractor/subcontractor safety records and performance audits are conducted.

- Contractor/subcontractors safety plan are reviewed and approved prior to contractor/subcontractor mobilization.

- Contractor/subcontractor safety meetings are attended by LLNL representatives.

- All necessary contractor/supervisor supervisors attend a customized sitespecific 10-hour OSHA class for supervision.

\section{I.A.9. System Engineers}

The System Engineers are individuals each responsible for a major project activity (e.g., Laser Systems). The System Engineers report to the Associate Project Engineers/Associate Program Leader.

- The System Engineer will take on all applicable safety responsibilities of the Construction Manager whenever a Construction Manager has not been assigned for the project activity of a System Engineer. See responsibilities of the "Special Equipment Construction Managers" above. 


\section{I.A.10. Safety Coordinator}

The Safety Coordinator reports to the NIF Assurance Office. Responsibilities include:

- Assist the Deputy Associate Project Engineer for Construction, the SE Construction Managers and the Activation and Start-up designee (to be determined) with the coordination of concurrent construction site work activities related to ES\&H among the three NIF Elements.

- Act as interface among NIF Elements on ES\&H issues pertaining to the construction site work activities.

- Assist in resolution of any interferences related to ES\&H issues among NIF Elements.

- Make final determination on issues of conflict (pertaining to ES\&H) among NIF Elements.

- Oversee environment compliance with permits, the Mitigation Action Plan, PEIS, etc.

- Act as the interface with DOE and other LLNL programs and directorates on ES\&H issues pertaining to the NIF Project and the construction site activities.

- Track ES\&H deficiencies and status of resolution during construction of NIF [i.e., Administers the ES\&H deficiency tracking database (DefTrack) for those deficiencies occurring on NIF construction site].

- Chair the Project Safety Team.

\section{I.A.11. Construction Safety Officers}

The Construction Safety Officers are assigned to the various Elements of NIF, and report to the Deputy Associate Project Engineer for Construction, the Field Construction Manager, a Special Equipment Construction Manager, a System Engineer, and/or the Activation and start-up designee (to be determined). $\mathrm{He} / \mathrm{she}$ is responsible for overseeing the safety of LLNL employees, non-LLNL employees, construction contractors and construction subcontractors associated with the NIF Element to which he/she is assigned during the construction of the NIF. Additional duties (i.e., responsibilities) may be delegated by the Deputy Associate Project Engineer for Construction, the Field Construction Manager, the Special Equipment Construction Managers, the System Engineers or the Activation and Start-up designee (to be determined) upon agreement. Responsibilities include:

- Support the Deputy Associate Project Engineer for Construction, the Field Construction Manager, the Special Equipment Construction Managers, the System Engineer(s) and / or the Activation and Start-up designee (to be determined) of the assigned NIF Element.

- Act as point contact and interface with Hazards Control ES\&H Team on construction site related ES\&H issues pertaining to the assigned NIF Element. 
- Review ES\&H aspects of construction site work of assigned Element with construction site work of other Elements.

- Assist with resolving ES\&H issues

- Review work practices of LLNL employees, non-LLNL employees, construction contractors and construction subcontractors (associated with the assigned Element) to assure all work is being performed in accordance with applicable ES\&H.

- Perform formal safety compliance audits and inspections, and document findings.

- Review results of safety compliance audits and inspections the Deputy Associate Project Engineer for Construction, the Field Construction Manager, the Special Equipment Construction Managers, the System Engineer(s) and/or the Activation and Start-up designee (to be determined); provide recommendations for correction (and prevention of recurrence) of non-compliance findings; and identify necessary follow-up measures to ensure future compliance.

- Assist the Deputy Associate Project Engineer for Construction, the Field Construction Manager, the Special Equipment Construction Managers, the System Engineer(s) and/or the Activation and Start-up designee (to be determined) with investigations of injuries, accidents, and incidents.

- Assist with preparation (and modifications) of Safety Plan for assigned NIF Element.

- Review Safety Plans of primary contractors/subcontractors to ensure such Plans are consistent with LLNL policies and the NIF Facilities requirements.

- Request and coordinate support of the Hazards Control ES\&H Team to resolve specific safety issues.

- Be a member of the Project Safety Team.

\section{I.A.12. Construction Inspectors.}

The Construction Inspectors are the primary field contact to the subcontractor for a specific NIF Element. Responsibilities include:

- Assure Quality Control for general, mechanical and electrical engineering work.

- Monitor the contractor's/subcontractor's safety program on a day-to-day basis.

- Notify the Deputy Associate Project Engineer for Construction, the Field Construction Manager, the Special Equipment Construction Managers, or the System Engineers when improper working conditions are identified.

\section{I.A.13. LLNL Employees}

LLNL employees are University of California employees whose payroll and benefits are administered by LLNL. Responsibilities include: 
- Know and understand the ES\&H requirements of their assignments and the potential hazards in the work area.

- Perform work assignments in full compliance with applicable ES\&H requirements in Laboratory manuals, guidelines, and established in the Safety Plan of the NIF Element for which they are assigned.

- Participate in all training, personnel, and health monitoring programs required by LLNL.

- Immediately correct or inform the responsible supervisor of any ES\&H-related problems.

\section{I.A.14. Non-LLNL Employees (Excluding NIF Construction Contractors and Subcontractors)}

Non-LLNL employees are visitors, students, participating guests, employees matrixed (or on assignment) from other National Laboratories, contract labor, supplemental labor and vendors, including those working for facility operations contractors. Non-LLNL Employees for purposes of this document do not include NIF Construction Contractors and Subcontractors (see Section I.B. for specifics). Responsibilities of Non-LLNL Employees include:

- Receive appropriate LLNL ES\&H training, or equivalent, or shall be escorted and supervised by personnel knowledgeable in the hazards to which they may be exposed.

- Receive the same pre-placement and ongoing medical surveillance examinations as LLNL employees based on occupational exposure(s).

- Report all work-related injuries and illnesses to NIF Program Management.

- Use the same protective equipment and safety controls required for any employee working in the area.

- Follow all safety and health requirements of their own parent organization.

- Follow LLNL and requirements governing the safe and orderly conduct of operations.

- Not be assigned tasks or duties that expose them to hazards beyond that specified in their contract.

- Perform work assignments in accordance with applicable ES\&H requirements in Laboratory manuals, guidelines, and established in the Health and Safety Plan of the NIF Element for which they are assigned.

With the exception of emergency first aid and respirator review and approval, Health Services does not routinely provide medical services to non-LLNL employees. Special examinations may be provided only if requested by LLNL management or is specified in contractual agreement. 


\section{I.B. NIF Construction Contractors and Subcontractors}

NIF Construction Contractors and Subcontractors are firms (or individuals) that are contracted or subcontracted to perform specific work tasks on the NIF construction site. Included under this category are:

- Sverdrup Facilities, Inc. (as related to their own employees).

- Firms or individuals contracted or subcontracted for NIF site work through the Conventional Facilities Element.

- Firms or individuals contracted or subcontracted for NIF site work through the Special Equipment Element.

- Firms or individuals contracted or subcontracted for NIF site work through the Activation and Start-up Element.

- Firms or individuals contracted or subcontracted by any of the above contractors or subcontractors.

All NIF Construction Contractors and Subcontractors shall:

- As a condition of their contract or subcontract, assume responsibility for the safety and health of their employees, agents, subcontractors and their employees, and other persons representing them on the Work Site.

- Assign an on-site "Competent" Safety Representative for each contract or subcontract whose duties include the protection of persons and property and the administration of the safety plan. The name of this individual shall be provided to the NIF Project Management upon award of the contract.

A "competent" safety representative is capable of identifying existing and predictable hazards in the surroundings or working conditions which are unsanitary, hazardous, or dangerous to employees, and who has authority to take prompt corrective measures to eliminate them. A "competent" safety representative is also an individual who has received the proper OSHA training necessary to understand and properly address unsafe conditions surrounding construction site exposures.

- The contractor's/subcontractor's "competent" safety representative must also attend and complete the 10-hour OSHA safety training course. This training will be provided upon contractor's request at no cost to the NIF.

- All contractors/subcontractors are required through CAL/OSHA's Injury and Illness Prevention Program (IIPP) to investigate accidents/incidents and to determine cause and to develop/implement corrective actions to prevent reoccurrence. All contractors/subcontractors are responsible to notify immediately NIF Project Management regarding any near misses or accidents. Completed accident investigation reports, findings, and corrective measures should be faxed to NIF Project Management once completed.

- Comply with CAL/OSHA's Title 8, Construction Safety Orders Article \#3, Section 1509 IIPP and all applicable laws, regulations, ordinances, conditions of 
contract/subcontract, rules or orders of any public authority having jurisdiction relating to safety of persons or property.

- Ensure that all of their employees, subcontractors and their subcontractors' employees, are briefed on applicable LLNL ES\&H policies/procedures and NIF's Facilities. All of their employees, subcontractors and their subcontractors' employees are required to attend a 30 minute safety orientation session that will be provided by the Construction Manager for Conventional Facilities in the onsite NIF Safety/Labor Relations trailer prior to performing any work on the site. Contractors/subcontractors shall, in accordance with law, adopt procedures providing that any employee who carelessly or callously disregards these rules or other applicable safety and health regulations shall be subject to disciplinary action up to and including discharge.

- Submit OSHA 200 logs and total man-hours worked on a monthly basis to the NIF Project Management.

- Have their safety representative participate in the safety walk-through meetings.

- The Contractor/Subcontractor shall ensure (with respect to their employees) that:

- Prior to the performance of any work, each employee involved in the NIF Project knows and understands each of ES\&H and security rules which applies to the job site in which he/she is performing for the Project.

- Each employee assumes responsibility for his/her protection. Personal protective equipment (inclusive of mandatory ANSI approved hard hat, appropriate NRR hearing protection, appropriate footwear \& ANSI approved safety glass) shall be used where required and maintained in proper condition.

$100 \%$ personal eye wear protection is required in all construction work areas and shall be worn at all times by employees of both the contractor and subcontractors, regardless of tier. Eyewear shall conform to applicable ANSI Z87.1.

Employees on walking and or working surfaces with unprotected sides or edges six feet (6) or higher above a lower level shall be protected from falling by the use of guardrails, or personal fall arrest systems. This shall include but is not limited to employees on the face of formwork, reinforcing steel or structural steel during and after erection, exterior and interior masonry work, roofing work, window installation, electrical work, mechanical work, and all other trades that require work in areas where the height exceeds six (6) feet above the ground or work surface.

- Employees do not engage in practical jokes and/or horseplay.

- An employee is not undertaking work which he or she is not properly qualified or equipped to do. In this regard, each employee shall be required to attend Safety Training Meetings weekly and sign an attendance sheet. 
- Employees are aware that use of intoxicating or unlawful substances during working hours is forbidden and any violation will be sufficient cause for dismissal and possible arrest. Employees reporting for work while under the influence of intoxicating or unlawful substances will not be allowed to assume their duties nor will they be allowed to return to the construction site.

- Employees are informed of proper storage requirements for hazardous materials (flammable, combustible, toxic, etc.) and hazardous wastes in accordance with the NIF Construction Storm Water Pollution Prevention Plan.

- Each employee is to be provided with information and training on the Hazard Communication Standard the employer's Hazard Communication Program, and Material Safety Data Sheets (MSDSs). In addition, each contractor/sub-contractor is responsible for making provisions to provide copies of MSDSs, and provide information on measures that need to be taken for personnel protection to all affected employees of other employers. Copies of MSDSs shall also be provided to the NIF Project Management.

- Contractors/subcontractors are responsible for daily cleaning of work areas and debris removal.

- Each employee must always know where he or she is in relation to work in progress, and avoid hazardous situations around equipment or construction in progress. Employees must advise supervisory personnel of their work location. They shall not work alone in an isolated area until arrangements have been made for periodic contact with another employee or supervision.

- Employees complete a pre-shift self-inspection checklist for safety hazards, and discrepancies to be corrected before work begins.

- One week prior to construction activities involving either construction operations or other hazardous operations, a Job Hazard Analysis (JHA) shall be prepared and submitted to NIF Project Management for review and approval.

- At the beginning of each shift there will be at least a 5 minute safety meeting to discuss the days activity with each crew and the activity they are to perform.

- Provide modified duty when available and case management procedures for all injured employees.

- Submit to NIF Project Management:

- A site specific safety plan, pre-work review and acceptance required. Note: A specific safety plan may not be required if the contractor or subcontractor is specifically addressed in the safety plan for the primary contractor or primary subcontractor.

- Name and qualifications of an on-site representative. (Note: Preapproval of the safety representative by NIF Project Management must occur prior to onsite work). 
- Current copies of weekly tool box/tailgate safety meetings, when requested.

- JHA pre-work and specific as required.

- Weekly project safety inspection and deficiency reports with solutions and corrections included.

- Current inventory of Hazardous Substances on site, accompanied by MSDSs.

- New employee orientation log.

- Current copy of OSHA 200 log for the project.

- Substance and Alcohol Abuse Prevention program.

- Completed accident, injury and incident reports within 24 hours of occurrence.

- A summary of all accidents and injuries including first aid to submitted weekly.

\section{I.C. Lasers Program Assurance Office}

The Lasers Programs Assurance Office provides a central programmatic interface and assurance function for ES\&H activities. Responsibilities include:

- Prepare program-wide ES\&H plans.

- Monitor and inspect program activities to assure that they are in compliance with program and LLNL ES\&H requirements.

- Track ES\&H deficiencies and status of resolution (i.e., administer DefTrack).

- Review occurrence reports and report incidences to the DOE.

- Concur with the CSP for NIF.

\section{I.D. LLNL Hazards Control Department}

The LLNL Hazards Control Department (HCD), which reports to the Associate Director for Plant Operations, assists Laboratory programs with reducing the risk of workplace hazards by providing expertise, guidance, and services. The goals of HCD's risk reduction efforts are to prevent accidents, maintain a safe workplace, minimize exposure to harmful agents, and control the impact that emergency situations may have.

Two divisions of the department will provide support during construction of the NIF Project as follows:

\section{I.D.1. Environment, Safety, and Health Team 2}

ES\&H Team 2 provides technical and oversight support to the NIF Project Office including the NIF Elements (e.g., Conventional Facilities, Special Equipment and Activation and Start-Up). ES\&H Team 2 will also assist in the coordination of the Construction Health \& Safety Programs for NIF's constructors/subcontractors. It is a 
key interface between the NIF Project Office (and its Elements) and the LLNL ES\&H support organizations. The team is comprised of safety and health specialists and technicians from HCD. In addition, specialist are assigned to ES\&H Team 2 from the LLNL Environmental Protection Department (EPD) and the LLNL Health Services Department (HSD). The Division Leader for ES\&H Team 2 is a member of the NIF Environment \& Safety Working Group and will concur with the CSP for NIF (this document). During construction of the NIF Project, the Division Leader may appoint one or more Construction Safety Officers (CSO) to the various NIF Elements, and assign them primary responsibility to support administration of the CSP for NIF.

During construction, the team's primary responsibilities include:

- Review of safety related materials and submittals from the NIF Project Office and the NIF Elements, which includes review of Construction Safety Plans submitted by first level/primary constructors/subcontractors.

- Audit of the NIF Project's safety performance, and advise the NIF Project Office and the Elements of their findings.

- Provide interpretation of all applicable health and safety codes in a manner consistent with University/Laboratory policies.

- Provide support during emergencies and as required during normal construction activities on the NIF construction site.

- Assist the NIF Office (including the NIF Elements) in identifying, analyzing and mitigating ES\&H hazards and concerns.

- Advise the NIF Project Office and NIF Elements on appropriate ES\&H related controls needed to eliminate or minimize the identified hazards and concerns posed by NIF construction activities, including special equipment installation, and initial activation and operation of NIF during the construction period of NIF.

- Periodically audit and document the NIF construction site for compliance with the requirements of this document, and advise the NIF Project Office and NIF Elements of non-compliance issues.

- Take appropriate steps to ensure that any activity on the NIF construction site that presents an imminent, uncontrolled danger to human safety, health, or the environment is immediately stopped.

- Assist the NIF Project Office, NIF Elements and Lasers Program Assurance Office during the investigation of accidents or incidents, and coordinates collection of certain required data for University/LLNL recordkeeping purposes.

- Supervise the activities of the construction safety engineers, technicians, and other ES\&H disciplines.

- Assist in the preparation of written safety procedures e.g., Operational Safety Procedures (OSPs).

- Provided technical support to the safety elements of the Readiness Reviews.

- Direct the activities of the on-site ES\&H Technician. 


\section{I.D.2. Emergency Management Division}

HCD, through its Emergency Management Division (EMD), manages the LLNL Fire Department and the LLNL On-Site Emergency Preparedness Program. The Fire Department provides a 3 to 5 minute response to fire, medical, and hazardous material incidents at the NIF construction site. The Fire Department will provide Basic and Advanced Life Support emergency care and emergency medical transport, for injuries or illnesses on the NIF construction site. The Fire Department on-scene Incident Commander has authority to call and direct appropriate LLNL and external resources, including ES\&H Team 2, Health Service Department, EPD, Livermore City/Alameda County fire units to control emergencies on the NIF construction site. The Fire Department is also in charge of the issuance of burn permits and must approve of all fire safety system (sprinkler, fire water or alarm) outages. The Fire Department may also inspect the site to insure compliance with the LLNL fire protection program, including proper emergency vehicle access.

The Division's Emergency Preparedness Administrator will assist the NIF Project Office in developing appropriate Self-Help plans for addressing site-wide emergency events.

\section{I.E. Risk Management Office}

The Risk Management Office is part of the Staff Relations Division of LLNL's Human Resources. Responsibilities include:

- Manage the Laboratory's Self-Insurance Program, which includes the Workers' Compensation and general liability programs.

- Maintain an awareness of current statutes, DOE orders, and other legal requirements to make sure the Laboratory complies with the State of California Workers' Compensation and other legal and financial mandates.

- Manage or coordinate the Laboratory's responses to any audits related to Workers' Compensation or insurance programs.

- Procure special insurance to meet unique risks.

- Serve as a resource to Laboratory management on insurance matters and requirements.

\section{I.F. Owner Controlled Insurance Program (OCIP) for NIF's Conventional Facilities}

The Owner Controlled Insurance Program (OCIP) for NIF is an insurance program managed by the Conventional Facilities Element of NIF, and is designed to provide insurance coverage to construction subcontractors while providing cost saving to the NIF Project. The OCIP will provide Workers Compensation, Builders Risk and General and Excess Liability insurance coverage SOLELY to the construction subcontractors 
(excluding Construction Package 1) working for the Conventional Facility Element of NIF.

As part of OCIP, NIF Project Management decided to incorporate Zero Injury Safety Techniques during the construction of NIF to reduce the potential of industrial injury at the work site from the substantial number of construction activities simultaneously occurring on the site. As such, all workers working at the NIF Construction Site will be required to follow the "Zero Injury Safety Techniques." The Techniques which apply to all Elements are incorporated into the CSP for NIF.

The following requirements of the OCIP pertain solely to Construction Subcontractors for the Conventional Facilities:

- The broker will provide administration of the OCIP for the Conventional Facilities Element of the NIF Project at LLNL, which will include monthly loss analysis reports.

- The broker will provide monthly loss reports and a monthly summary of safety activities which identifies exposures and recommendations to mitigate such exposures.

- The broker will provide, as requested, Safety Consultant services to assist Conventional Facilities Management, inclusive of:

- physical hazards site surveys

- attendance at pre-construction and safety committee meetings

- participation in the contractor's safety orientation

- technical review and interpretation of standards/regulations

- The broker and the carrier representatives will monitor the site Loss Prevention Program and assist participating contractors and subcontractors as a technical resource as needed.

- The broker and the carrier will perform audits of the Health \& Safety Plans for the Conventional Facilities subcontractors as requested.

- Both parties will review loss history, trend occurrences and recommend management controls to minimize exposures to loss.

- The broker will provide quarterly status reports for NIF OCIP. Include in the report:

- Safety Compliance Records of project status for participating contractors, subcontractors, and other project participants.

- Statistical comparisons of participating contractors and subcontractors to national averages and to each other.

- Claims cost and loss ratio comparisons of contractors and subcontractors. 


\section{I.G. Project Safety Team}

The Project Safety Team shall consist of individuals from LLNL support organizations, the NIF Project Office, the NIF Element, and the Department of Energy.

The Team shall strive to meet the goals and objectives within the CSP for NIF, inclusive of:

- Keeping the NIF Project Manager informed on events and progress pertaining to ES\&H issues.

- Monitoring the development of the CSP and confirming that the following items are appropriately addressed:

- Occupational Safety

- Occupational Health

- Employee ES\&H Orientation \& Training

- Potential Hazards

- Accident Investigations

- Documentation for Site Audits and deficiencies resolution.

- Equipment Inspections

- Environmental Monitoring and Regulatory Compliance

- Emergency Contingency Plans (medical, fire, etc.)

- Confirm that worker ES\&H education and orientation requirements are met.

- Verify that safety briefings are conducted.

- Conduct construction site safety compliance audits and record reviews in preselected work areas of the Construction Site. Audits will be coordinated by the cognizant Construction Manager (or System Engineer) and the Construction Safety Officer.

- Review the results of the audits for compliance, recommendations made for correction and prevention of recurrence, and follow-up measures taken to ensure compliance.

- Review records of all accidents experienced by LLNL employee, non-LLNL employees, construction contractors or construction subcontractors.

- Provide recommendations for material and personnel resources required to effectively and efficiently achieve the requirements of the CSP for NIF. 


\section{I.H. NIF Safety Organization Chart}

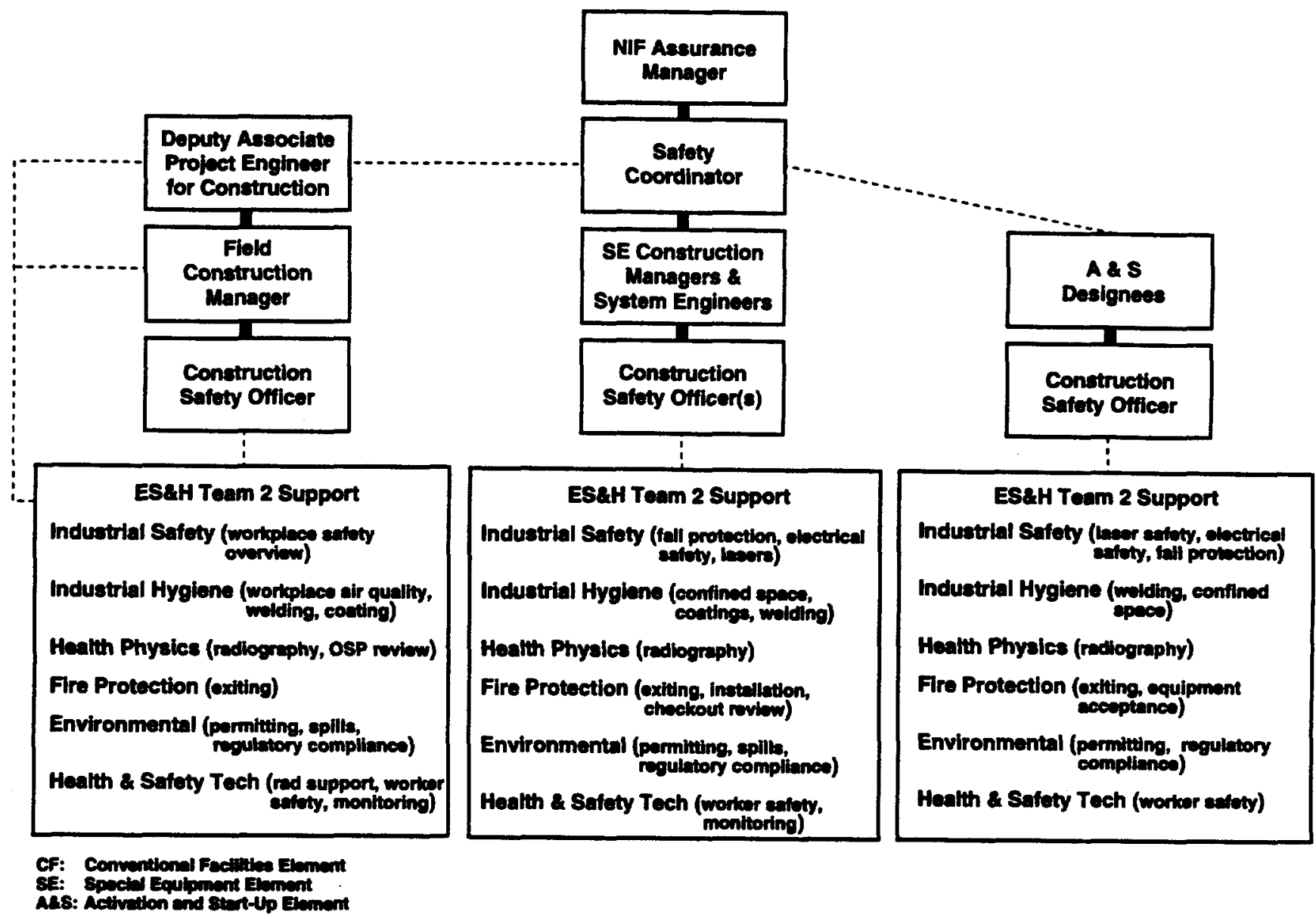




\section{Stop-Work Authority and Procedures}

The stop-work procedure at the Laboratory (see section 1.9 of the LLNL Health $\&$ Safety Manual) applies to all NIF construction activities. The stop-work procedure will be used only where imminent-danger situations exist. A stop-work order affects only those areas of the NIF construction project immediately involved in the hazardous situation. When a stop-work order is issued on the NIF construction site, the NIF Safety Coordinator and the Division Leader for ES\&H Team 2 shall be immediately notified by the Deputy Associate Project Engineer for Construction, cognizant NIF Construction Manager, System Engineer, or on-site Safety personnel.

\section{II.A. Imminent Danger Situations}

A stop-work order is normally issued by the Deputy Associate Project Engineer for Construction, a cognizant Construction Manager, the Construction Safety Officer, or the NIF Construction Inspector. If they are absent and a construction contractor's/subcontractor's personnel are involved in an imminent-danger situation, Hazards Control personnel are authorized to directly contact the personnel and stop the operation. The construction inspector, Deputy Associate Project Engineer for construction, cognizant Construction Manager, or safety coordinator shall then be immediately located and contacted by Hazards Control and informed of the stop-work order.

\section{II.B. Other Situations}

A stop-work order may be issued by the Deputy Associate Project Engineer for construction or the SE Construction Manager for a portion of the work area(s) or the entire work area when, in his/her opinion, the work area is not being maintained according to the requirements of this document and/or the construction contractor's/subcontractor's Health \& Safety Plan. The stop-work order will be in effect until the construction contractor/subcontractor resolves the problem(s) and brings the work area(s) to satisfactory conformance with health and safety requirements. Stopwork orders are normally not issued for this reason unless the contractor/subcontractor shows a consistent disregard for construction safety or ignores/refuses to correct deficiencies when they are discovered by University/Laboratory personnel or their representatives.

\section{II.C. Differences of Opinion}

Differences of opinion (relative to a stop-work order) between the Hazards Control representation, Deputy Associate Project Engineer for Construction, Field Construction 
Manager, SE Construction Manager, Construction Safety Officer, or Construction Inspector concerning a stop-work order shall immediately be referred to their respective line management for resolution.

\section{II.D. Resumption of Work}

After a stop-work order has been issued, a resumption of work requires the concurrence of both the NIF Project Office Assurance Manager or Safety Coordinator and the Division Leader for ES\&H Team 2.

A formal Incident Analysis Report may be required after each instance in which work has been stopped (reference section 4.08 of the LLNL Health \& Safety Manual). 


\section{Accident/Incidents}

\section{III.A. Emergency Assistance Procedures}

All calls for emergency assistance, whether they be for medical aid, fire fighting, rescue, etc. will be requested by telephone through the LLNL Hazards Control Department's Emergency Management Division (EMD) Dispatch Center by dialing 911 from an on-site LLNL telephone or 447-6880 from a cellular telephone or other telephone that is not connected to the LLNL Telephone Exchange (LLIX). Calls to the Dispatch Center are answered by an EMD Dispatcher, who will send fire and/or paramedics units to the emergency at the NIF site. A Hazards Control Department Health and Safety Technician will also respond to all emergencies called into the Dispatch Center. As appropriate EMD may request other LLNL or external resources to assist in control and mitigation of the emergency incident.

\section{III.B. Self-Help Plan}

LLNL realizes that during a major emergency, such as an earthquake, external help may not be immediately available. Therefore, the philosophy of emergency preparedness at LLNL relies upon the resources of individual organizations on-site to protect the welfare of Laboratory workers, this program is known as the "Self-Help Program" (SHP).

For the construction phases of the NIF, the NIF Project Office will be responsible for preparing and maintaining a SHP plan to address the impact that major LLNL emergency situations would have on the NIF construction site. The NIF Project Office shall consult with both the Laser Program and LLNL Self-Help Managers on the development of this plan. The plan at a minimum shall provide for:

- Accounting of personnel working on the NIF site.

- Maintaining the safety and well-being of personnel on the NIF site.

- First-aid response in the absence of assistance from LLNL resources.

- Locating and rescuing trapped or injured personnel.

- Locating and reporting obvious damage to facilities.

- Control of personnel on the NIF site until LLNL site evacuation plans have been coordinated by the LLNL Emergency Management Center (EMC) and external local law enforcement authorities (e.g., CHP, Livermore Police). 
LLNL is divided into self-help zones, each under the direction of a zone supervisor-the NIF construction site is located in Zone 14. Within each zone, there are fixed assembly points-the NIF construction site will have its own assembly point. Each assembly point has a leader who directs local emergency activities from these locations. The zone supervisor provides advice and recommendations to the Assembly Point Leader (APL) and keeps them advised of conditions on the LLNL site and within the zone. They are also responsible for relaying EMC orders to zone personnel, including those on the NIF construction site.

At a minimum the NIF Project Office will designate an APL for the NIF construction site, who upon activation of the LLNL Self-Help Program shall supervise emergency activities on the NIF construction site. With respect to the NIF construction site their responsibilities include: accountability, care, and protection of personnel; first-aid, transporting the injured, situation assessment and reporting, and protection of facilities within the site; and search and rescue operations by the volunteer re-entry (sweep) teams. The APL will request assistance for the NIF site as needed. The APL will communicate information (e.g., personnel accountability, injury/damage reports) to the Laser Program Zone Supervisor/Control Point.

\section{III.C. Flooding}

The NIF Construction site is located above the 100 year flood plain and will not be affected by flood of this magnitude. The main threat from flooding at the NIF Construction Site is due to overflow of the Arroyo Las Positas from excessive precipitation (such as that which may occur during a 2000 year flood). Generally, severe flooding from excess precipitation develops relatively slowly. This would allow the opportunity for mitigative actions to be taken, such as securing hazardous material inventories and moving them to safe locations.

Mitigative actions for hazardous material inventories will be initiated whenever ALL of the following conditions are met:

1. The Arroyo Las Positas has reached maximum capacity.

2. Rainfall is occurring and continued rain is forecasted.

3. Large pools of standing water exist and are increasing in size on the Construction Site.

Mitigative actions will consist of moving hazardous material inventories to a secured, covered area/structure on the LLNL Site which is located on higher ground, and anchoring or weighting items if left at ground level.

Each construction contractor/subcontractor is responsible for taking appropriate actions for the inventories under their control. NIF Construction Management, and as necessary LLNL emergency management/response personnel, will oversee flood mitigation activities. 


\section{III.D. Medical Services and First Aid}

Employers on construction sites are required by OSHA to insure the availability of medical personnel for advise and consultation on matters of occupational health. This section describes how this will occur on the NIF construction site.

On a 24 hour basis, EMD is available to dispatch paramedics to seriously injured individuals on the NIF construction site and will arrange to transport injured individuals to appropriate medical treatment facilities - either on or off of the LLNL site.

The NIF Conventional Facility Element has not elected to have its construction contractors/subcontractors use LLNL's Health Services Department for first aid.

As authorized by NIF Project Management, other construction contractors / subcontractors may elect to utilize HSD for providing emergency first aid to their employees working on the NIF project (refer to contract terms). If HSD is not used, the contractor/subcontractor shall have available at their worksite a person-who has a valid certificate in first-aid training from the American Red Cross or equivalent training that can be verified by documentary evidence - to render first aid when required.

Each contractor/subcontractor shall have at their worksite physician approved firstaid supplies that are easily accessible to their employees when required. First-aid kits used for this purpose shall be in weatherproof containers with individually sealed packages for each type of item. The contents of the first-aid kit shall be checked by each contractor/subcontractor at least weekly to ensure that the expended items are replaced.

In the case of less serious injury or illness, all NIF construction contractors/ subcontractors shall determine in advance of their working on the NIF construction site where their employees are to be treated. This determination shall be clearly noted in their safety plans and communicated to their employees. LLNL employees will be treated at HSD. Non-LLNL employees will be treated in accordance with the provisions and agreements contained in their employer's individual contract with the University/LLNL. Persons with minor injuries may be transported to local medical facilities by supervisors, coworkers, or by themselves as appropriate.

If any individual (employee, construction contractor, subcontractor, visitor, etc.) of the NIF Construction Project notifies HSD of an occupational illness or injury, Health Services will relay pertinent information to the Hazards Control Department. Hazards Control will then initiate a Supervisor's Accident Analysis Report (SAAR) and forward a copy to the NIF Project Management so that the appropriate investigation may be conducted (see III.E.) 


\section{III.D.1 Health Services Availability}

During normal weekday working hours (8:00 A.M. to 4:45 P.M.): For LLNL employees: first aid and medical treatment cases may be referred to HSD (Building 663) for emergency evaluation and emergency treatment, and for other services including medical treatment and case management as arranged for by NIF Project Management. For contractor/subcontractor, and non-LLNL employees: further treatment beyond emergency care will have to be arranged by the cognizant party or employer.

After normal working hours (before 8:00 A.M. or after 4:45 P.M., and on weekends): For LLNL employees: all non-emergency first aid and medical treatment cases will be referred to either Valley Care Medical Center, Eden Medical Center's Trauma Clinic, or to the nearest medical provider of choice. For contractor/subcontractor employees: non-emergency first aid and medical treatment cases will be referred as called for in the OCIP program or local labor agreements.

For LLNL employees: on-site medical personnel may be contacted directly by calling:

\section{LLNL Health Services - 510 422-7459*}

For LLNL employees: off-site medical personnel may be contacted directly by calling: (TBD) Occupational Clinic - $510 \times X X-X X X X X^{*}$

\section{III.E. Reporting and Investigation Procedures}

\section{III.E.1. Policy and Scope}

It is the policy of the NIF to investigate all near miss incidents and accidents/incidents related to the construction program which result in personnel injury or illness, or damage to buildings or equipment, as a result of an accident or natural phenomena. It is the Construction Contractor's/ Subcontractor's obligation to investigate all occurrences, provide all information outlined below, and submit the information to Construction Management. Contractors/Subcontractors shall cooperate fully with the investigation of occurrences conducted by LLNL, the University of California, or the U.S. Department of Energy (DOE).

\footnotetext{
"NOTE: These telephones numbers should not be used for emergencies. They should be used only when medical advice is needed concerning first-aid type injuries or when complications might arise following release from medical care. These numbers should also be used when there are questions regarding medical problems and where to go for treatment and care.
} 


\section{III.E.2. Purpose}

The purpose of investigating job related accidents and illnesses is:

- To determine cause for the purpose of preventing recurrence, and in some instances, to determine whether gross negligence was involved.

- To comply with applicable federal, state, and local codes and regulations and contractual requirements relating to loss and occurrence reporting.

- To provide documentation of occupational injuries and illnesses, and to assist in Workers' Compensation claims management.

- To ensure objective releases to the news media.

- To comply with LLNL Incident Analysis and Lessons Learned requirements

\section{III.E.3. Occupational Injuries/lllnesses Notification and Reporting}

All individuals who are injured on the NIF construction site, however minor, or suspect they have developed an occupational illness shall immediately notify their onsite supervisor or NIF Project contact. In turn, the on-site supervisor or NIF Project contact will immediately notify the NIF Construction Manager, Construction Safety Officer, or NIF Safety Coordinator who shall immediately evaluate the seriousness of the injury for additional internal notification and internal reporting (see III.E.4, III.E.5, and III.E.6).

LLNL employees and non-LLNL employees shall report injuries and occupational illnesses in accordance with existing LLNL procedures and their contractual requirements.

\section{III.E.4. Incident Reporting}

In addition to personnel injury or illness reporting requirements as described in Section III.E.3, above, all incidents which result in damage to buildings, materials, or equipment; reportable releases to the environment of hazardous materials; violation of environmental permit conditions; Safeguard and Security violations; or transportation accidents must be reported to the NIF Construction Management immediately. The NIF Construction Management will immediately notify the appropriate LLNL Organization, and the NIF Safety Coordinator or Assurance Manager, who will in turn notify the Laser Programs Assurance Office contact.

\section{III.E.5. DOE Occurrence Reporting Requirements}

Depending on the severity of the incident the DOE Occurrence notification requirements for which the University/LLNL are contractually obligated to comply with may be triggered. DOE must be notified of an incident, which LLNL has determined as reportable to them, within 2 hours of the occurrence of the incident. As such, immediate notifications through the chain of command is essential so that LLNL's procedures for categorizing and determining if DOE notification is required may occur. 
The NIF Assurance Office together with the Laser Program Assurance Office contact, and in consultation with LLNL ES\&H Team 2 if necessary, will make the determination as to whether or not an incident is reportable to the DOE.

\section{III.E.6. Investigation Procedures}

- All injury, property damage, fire, incidents and accidents will normally be initially investigated by the supervisor in charge of the area of occurrence, who is on duty at time of occurrence.

- For reporting, investigation, and recordkeeping purposes of occupational injuries and illness related to NIF construction activities the following applies:

For NIF Construction contractor/subcontractor personnel the appropriate forms (California State 5020 "First Report of Injury", and a NIF Accident/Incident Investigation) must be forwarded immediately to the Contractor's Safety Representative and NIF Construction Management for review.

For LLNL employees and non-LLNL employees working under the direct supervision of LLNL, a "UC/LLNL SAAR" form shall be used to investigate and document work related injuries and illnesses.

- Investigation results will be reported in writing on the NIF Accident Investigation report form or SAAR. Completed copies shall be sent to the University's representative (ES\&H Team 2 Construction Safety Officer), NIF Construction Management, and the NIF Safety Coordinator within 5 working days. When essential information is lacking, the report will be returned to the originator for immediate completion. Information from these report forms will be transcribed into the University/LLNL injury and illness recordkeeping system by the LLNL Hazards Control Department, and as required transmitted to the DOE.

- In the event an injury is or has the possibility of being a fatality, or there is serious or fatal injury to a non-employee, or there are multiple serious injuries or extensive damage to any property, in addition to the above notifications of section III.E.3., IMMEDIATE notification will be made to NIF Project Office, the insurance carrier safety consultant (TBD), and the insurance broker.

- A serious injury or illness is one which requires worker hospitalization for more than 24 hours for other than medical observation, or in which a part of the body is lost or permanent disfigurement occurs. The scene of any major accident must be secured until documentary, photographic, and physical evidence can be preserved. No material, machinery, or equipment should be moved until approval is given by the LLNL Associate Director for Laser Programs , or his/her representative, unless the condition or physical position poses an additional hazard.

In the event an incident results in a fatality on the NIF construction site, the University of California Police Department at LLNL shall take control of the incident scene pending investigation by local authorities (i.e., Alameda County 
Coroner Office and/or District Attorney, OSHA, DOE) having jurisdiction over occupational fatalities.

- All official notifications to the family of an injured worker will be made by the Employer of the injured worker(s).

- Construction Contractors/subcontractors and their employees or agents, LLNL employees and non-LLNL employees are not to discuss with the media any facts, hearsay, or assumptions regarding accident/incidents occurring during the NIF construction project. ALL releases to the news media must be either made by or approved by the University.

- A synopsis of all serious accidents, incidents or potential problems will be distributed to all NIF Construction Contractors/subcontractors and are to be addressed in a Special Safety Incident Investigation Meeting. This meeting, in which all construction contractors/subcontractors will be represented, shall be conducted within 48 hours of the incident, to formally discuss common hazards, serious accidents or where information requires timely communication. Pertinent information from this meeting shall be passed on by contractors/subcontractors to their employees.

- All NIF Construction Contractors/subcontractors shall provide modified duty and case management procedures for all injured employees.

\section{III.E.7. Injury Report Retention}

All reports pertaining to injury or illness of employees or non-employees shall be preserved and not destroyed without approval from the Contractor's Safety Representative and NIF Project Management.

Reports will not be released to anyone without approval of the NIF Safety Coordinator, and will be kept on file for five years following the date of occurrence. Injury and Illness records on LLNL employees are covered by the DOE moratorium on the destruction of epidemiological records and will be maintained in accordance with University and Laboratory policies. 


\section{III.F. Privacy Notification}

Any person working on the NIF construction site who is requested to provide personal information for accident or incident investigation purposes is to be notified, in accordance with University policy, of the following:

\section{University of California \\ Lawrence Livermore National Laboratory \\ Privacy Notification}

The Laboratory collects and maintains information about each employee for use in miscellaneous payroll and personnel matters. The following notice with respect to that information is provided as required by the California Information Practices Act of 1977:

The principal purpose for collecting and maintaining this information is for use in matters such as but not limited to payment of earnings, withholding of State and Federal taxes, effecting authorized payroll deductions, reimbursement for travel costs, and the administration of compensation, benefits, health and safety, and general personnel programs. Laboratory and University policy and State and Federal statutes authorize the collection, maintenance, and use of this information.

The furnishing of the information requested for these purposes is mandatory-failure to provide such information will delay and may prevent the completion of payroll and personnel actions. The information furnished will be used by various Laboratory and University departments for the above-described purposes and will be transmitted to Federal and State governments as required by law.

Individuals have the right to review their own records in accordance with Laboratory and University policies. Information on these policies may be obtained from the Human Resources Manager.

The officials responsible for maintaining the above-described information are the Human Resources Manager, the Accounting Officer, the Business Services Manager, the Assistant Laboratory Director for Plant Operations, the Head of the Hazards Control Department, the Head of the Health Services Department, and the Manager of Administrative Information Services.

The above notification may be incorporated into the NIF Accident/Incident form or provided separately to the individual. 


\title{
III.G.Sample NIF Accident/Incident Investigation Form
}

\author{
NIF CONSTRUCTION PROJECT
}

\section{ACCIDENT/INCIDENT INVESTIGATION FORM}

\section{PERSONAL INFORMATION}

1. Name of Injured

Date of Hire

Date of Birth

- Prime Contractor Subcontractor

Job Title SS\#

hr/monthly Telephone\#_-_-

2. Injury Date: I_Time: $\mathrm{am} / \mathrm{pm}$ Medical Care? Y/N

Treating Hospita//Clinic/Physician?

Has employee returned to work? (YN, date \& time)

3. Accident Location: (Specific Site Location with reference points):

4. Type of Injury:

$$
\text { Body Part(s) }
$$

Signs/Symptoms

5. Work Being Done:

6. Employee trained for work? Yes_No _ When?

Date Trainer: Name/Title

7. Employee authorized for work? Yes_No _ If yes, 
EMPLOYEE ACCIDENT INVESTIGATION FORM (continued)

\section{ACCIDENT DESCRIPTION}

8. Accident Description: (who, when, where, how, why)

9. Result of Site Investigation: (area coned off, new procedures)

10. Result of Tool/Equipment Investigation: (defective, wrong tool)

11. Primary Accident Cause(s) \& Contributing Factors:

12. Name \& job position:

\section{WITNESS(ES)}

Relation to injured party:

Description of incidents leading to injury/illness: (one-on-one interview) 


\section{EMPLOYEE ACCIDENT INVESTIGATION FORM (continued) RECOMMENDATIONS}

13. Job covered by: a. Job Hazard Analysis?

b. Safety rule/regulation: Bulletin, Document, Manual, Instruct. Handbook, Bulletin (Citation)

14. Is the procedure/rule/regulation adequate? Yes_No.

15. If no, recommended change(s):

16. Recommendation to prevent similar accidents:

17. Investigator(s):

Date:

19. Reviewed by:

Title

Date 1 L IL

20. Safety Committee review \& analysis: (suggestions for prevention of reoccurrence)

21. New procedures/training/controls implemented? Date _ ___ List changes

Additional information and/or comments: 


\section{Drug Free Workplace Program}

\section{IV.A. Applicability}

All NIF construction contractors/subcontractors are required to adhere to the Drug/Alcohol Policy set forth in section IV.B and IV.C of this document.

All Laboratory employees of the University working on the NIF construction site are covered by current LLNL policy.

All employees of other contractors/subcontractors working under the direction of LLNL on the NIF construction site are covered by the applicable provisions of their individual contracts with the University/Laboratory.

\section{IV.B. NIF Drug Free Workplace Policy Overview}

Being under the influence of a drug or alcohol on the job may pose serious safety and health risks not only to the used but to all those who work with the user. The possession, use or sale of an illegal substance or use of alcohol in the workplace also pose unacceptable risks for safe, healthful and efficient operations. The NIF Project Office Drug Free Workplace Program and Policy prohibits the possession, distribution, use, consumption or being under the influence of unauthorized alcohol, illegal and unauthorized substances (synthetics, designers, and other harmful substances) in order to provide a safe and healthful environment for our employees, the contractor's employees, customers, suppliers, visitors and members of the general public.

\section{IV.C. Requirements for NIF Construction Contractors/Subcontractors}

\section{IV.C.1. Substance Testing Program}

The Contractor/Subcontractor shall adopt and enforce a substance testing program at no cost to LLNL which complies with appropriate federal regulations and utilizes a Department of Health and Human Services certified laboratory. Under the substance testing program, the Contractor/Subcontractor shall test all new employees within the first 5 days of their employment at the site.

The Contractor/Subcontractor shall also test its employee upon reasonable suspicion of that employee's use of controlled substances, or abuse of legal substances on an LLNL site or after that employee's involvement in a NIF construction accident.

The Contractor/Subcontractor shall review the test results and the circumstances, and determine what action, if any, should be taken. The Contractor/Subcontractor shall advise the Construction Manager of any positive test results, and of its 
determination as to action, if any, to be taken. LLNL may deny access to the LLNL sites to any individual who tests positive on a substance screening test.

\section{IV.C.2. Definitions}

As used herein, the following terms shall have the indicated meanings:

"Alcohol" means the intoxicating agent in beverage alcohol, ethyl alcohol, or other low molecular weight alcohols including methyl and isopropyl alcohol (reference 49 CFR 382.107).

"Controlled Substance" means a controlled substance in Schedules I through V of Section 202 of the Controlled Substances Act (21 U.S.C. \$812), and as further defined in the regulation at 21 CFR 1308.11-1308.15.

"Substance Testing" means laboratory testing for legal or illegal substances in the urine or for alcohol in the blood or on the breath.

"Legal Substance" means: (1) Controlled substances that are prescribed or administered by a licensed physician; (2) Over-the-counter purchased legally; and (3) Alcoholic beverages.

"Illegal Substances" means controlled substances listed in 21 U.S.C. \$812, which are not legally obtainable, or those which are obtained illegally. 


\section{Pre-Phase Planning-Job Hazard Analysis (JHA)}

\section{V.A. Scope}

This section outlines the purpose for and method of Pre-Phase Planning-Job Hazard Analysis that will be required for each construction operation involving operations and/or work. All groups working on the NIF site including NIF Elements, LLNL Plant Operations and their contractors, supplemental labor, labor only contractors, and Construction contractors/subcontractors are responsible to complete a Job Hazard Analysis form one week prior to performing the operation and/or construction activity. A review by the NIF Construction Manager must be obtained prior to performing any on-site work activity.

\section{V.B. Purpose}

The purpose of accident prevention preplanning is to prevent unnecessary hazards that are likely to occur during construction of NIF and to make sure each group performing an operation/activity will have the necessary material and equipment on hand when needed. Due to the speed at which construction jobs proceed, it does not allow a single operation/activity to continue long enough to become safe through trialand-error. To cope with safety problems peculiar to the construction industry, this procedure has been established so construction management can predetermine the hazards and develop an appropriate plan to prevent the hazards from becoming accidents.

\section{V.C. Responsibility}

It is the responsibility of the NIF and LLNL Supervisors and the contractor's/subcontractor's safety representative to ensure that Pre-Phase Planning Job Hazard Analysis is done for all divisions of work operations and activities performed on the NIF site.

Pre-Phase Job Hazard Analyses will be developed by the field supervisory personnel who will be actually running the job(s) or operation(s) that is being preplanned. This analysis will be done on the attached "Job Hazard Analysis" form.

The supervisory personnel referenced in Section V.A above for each respective group or contractor/subcontractor will consult and coordinate the preparation of prephase plans with the cognizant Construction Manager (or Deputy Associate Project Engineer for Construction) and the Construction Safety Officer to ensure acceptable 
plans. In addition, the plans will be reviewed and updated at reasonable periods of time to include unanticipated hazards and changes in job conditions.

\section{V.D. Pre-Phase Meeting}

After the responsible supervisory personnel have completed their necessary preparations and have a pre-phase Job Hazard Analysis written out on the attached form, the cognizant Construction Manager (or Deputy Associate Project Engineer for Construction) will call a prephase meeting. This meeting will always be attended by the supervisory personnel of the LLNL group(s) or contractor(s)/subcontractor(s) submitting the plan, the cognizant Construction Manager, a Construction Safety Officer, and any other supervisory personnel responsible for that particular phase of work. Copies of the written plan will be distributed to all those present and the originator of the plan will be asked to go down his/her list of items explaining each one as he/she goes and allowing comments from all those present. Under no circumstances is work to be allowed to begin without first having the JHA reviewed.

\section{V.E. Construction Activities}

Construction activities requiring pre-phase Job Hazard Analysis plans are not fully inclusive to but will include the following:

- Demolition.

- Excavation and trenching.

- Earthwork, pile driving, paving.

- Concrete and masonry work.

- Structural steel erection including metal decking, miscellaneous steel.

- Roofing and waterproofing work, including metal roofing and siding.

- Mechanical work.

- Scaffolding work.

- Electrical work.

- Conveying systems.

- Hazardous chemicals use.

\section{V.F. Different Phases}

Listed below are only some of the items that should be considered in the different phases of construction: 
- Layout of haul roads, speed limits, access roads, storage areas, utilities, shop area, offices, fuel storage tanks, parking areas, electrical distribution lines.

- Temporary electrical installations (methods of supplying electrical power and lighting).

- Types of equipment to be used.

- Types of protective equipment used.

- Method of cleanup (types of equipment and procedures planned for use).

- Methods and coordination of handling materials.

- Concrete construction (type of forming, shoring, erection of precast concrete, lifting, placing, etc.).

- Access to work areas and work platforms.

- Methods of minimizing exposure to falls.

- Method of steel erection (bracing, temporary flooring, protection of steel workers).

- Methods of scaffolding.

- Methods of lighting.

- Methods of painting (health hazard involved).

- Connecting and disconnecting utility services (gas, water, electrical, sewers).

\section{V.G. Pre-Job Safety Planning and Hazard Recognition Checklist}

From his/her position of broad coverage, the supervisor must spearhead planning, working, and vigilant surveillance to eliminate hazardous conditions and actions which might result in bodily injury, property damage, and public liability. The following is a partial checklist of functions which the supervisor (by reason of their position) must personally initiate and follow up:

\section{V.G.1. Establish project safety policy}

1. Firmly communicate, implement and back the NIF/LLNL Safety policy throughout project.

2. Establish special rules for specific projects and publish them for your crew(s) and/or subcontractors.

3. Attend and participate in tool-box/tail board safety meetings.

4. Comply with OSHA's ruling that a qualified and certified first-aid person be available on-site at all times when work is in progress. Valid First-Aid Cards must be present.

5. Owner, government representative, and visitor protection.

6. Enforcement of vehicle policy and energy conservation effort. 
7. Conduct new employee orientations.

\section{V.G.2. Planning for safety}

1. All groups working on the NIF site are responsible for completing a Job Hazard Analysis form one week prior to any operation and/or work.

Construction Management review must be obtained prior to any on-site hazardous work activities. A minimum of 5 minutes will be used at the start of every shift to discuss the work for the day and the safety planning, precautions and requirements to be taken to mitigate the risk of an injury. This activity shall be documented. All changes to work activity through out the day will require the same safety and preplanning commitment.

2. The schedule for work initiates the communications to key people on the various activities of work which are expected to be going on and what to be alerted to safety wise.

3. Don't create or increase hazardous conditions via the schedule through lack of advance recognition of hazards. Layout project to include:
a. Safe and efficient access by foot and for vehicles, crane-way access, reaches, loads, and crane certifications.
b. Provision for employee parking in designated areas.
c. Yard layout to provide security and reduction of fire hazards.
d. Planned orderly storage and security of construction materials and equipment.
e. Sign live underground and overhead utilities.
f. Survey and control electric utility hazards.
g. Safety factored shoring, sheeting, and bracing.
h. Vertical and horizontal member checks.
I. Security from wind and flood.
j. Select proper crane for application.

4. Elimination of hazards to public:
a. Barricades, signs, and fences.
b. Cave-ins, flooding, dust, and wind.
c. Insecure loads, binders, and overhangs.
d. Restricted, rough roadways.
e. Poor sight distances and blind corners.

\section{V.G.3. Mitigation of property damage}

1. Property owned by others:

a. Overhead and underground utilities.

b. Cave-in and flooding. 
2. The project you are constructing:
a. Storm, freeze, and wind damage.
b. Signing temporary and permanent "hard to see" installations (pipe) (wire).
c. Fire protection and housekeeping.
d. Flooding $\rightarrow$ storm and manmade.

V.G.4. Special supervisor considerations

1. Job security (including non-working hours).
a. Fire, earthquake, flood, wind, and freeze.
b. Security, lighting, flashers, and locks.
c. Internal and external theft and vandalism.

2. Special alert about backing equipment (lifts \& mixers).

3. Pacesetting hazard recognition and accident prevention for the project.

4. Indoctrination of new hires.

5. Avoidance of "lone worker."

6. Training engineer, craft superintendents, foreman, and workers to participate in hazard recognition, along with efficient high production, morale, and schedule consciousness.

7. Awareness of Laboratory service equipment and Laboratory bike traffic movement and right-of-ways. 
FORM S+H 5-1-JOB HAZARD ANALYSIS

\begin{tabular}{|c|c|c|}
\hline \multicolumn{2}{|l|}{ JOB HAZARD ANALYSIS } & Date: \\
\hline \multicolumn{2}{|l|}{ Contract: (if applicable) } & Phase: \\
\hline \multicolumn{2}{|c|}{ LLNL Group/Contractor/Subcontractor: } & Location: \\
\hline \multicolumn{2}{|l|}{ NIF Element: } & Location: \\
\hline ACTIVITY OPERATIONS & $\begin{array}{l}\text { UNSAFE CONDITION, } \\
\text { ACTION OY OTHER HAZARD }\end{array}$ & $\begin{array}{l}\text { PREVENTATIVE or } \\
\text { CORRECTIVE ACTION } \\
\text { THAT WILL BE TAKEN }\end{array}$ \\
\hline & & \\
\hline & & \\
\hline & & \\
\hline & & \\
\hline & & \\
\hline & & \\
\hline & & \\
\hline & & \\
\hline & & \\
\hline & & \\
\hline & & \\
\hline & & \\
\hline & & \\
\hline & & \\
\hline & & \\
\hline & & \\
\hline 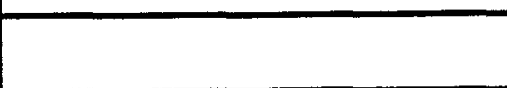 & & \\
\hline
\end{tabular}




\section{Training}

\section{VI.A. General requirements}

\section{VI.A.1. Bulletin Board}

A bulletin board shall be placed prominently next to the Construction Site Office or as otherwise directed by the cognizant Construction Manager or NIF Project representative. This board shall post the following bulletins:

- Emergency phone numbers: Livermore-dial 911 on site and 447-6880 from outside the Laboratory or Cellular Telephone.

- Dates and times that supervisors' safety meetings will be held (minimum of one per week).

- Dates, times, and places of tool box meetings, and requirements for attendance (minimum of one per week).

- The required DOE announcements and bulletins.

- Miscellaneous safety posters (DOE, LLNL, Worker's Compensation, etc.).

- Locations of on-site MSDSs.

\section{VI.A.2. Safety Meetings}

Safety meetings shall be held weekly for all employees. The purpose of these meetings is to educate and train employees and develop the proper safety attitude in the performance of their jobs. Proper handling of hazardous materials shall be covered prior to their use on the job site. Attendance records shall be maintained at the job site.

\section{VI.A.3. First-Aid Stations}

All personnel shall also be instructed in emergency procedures, first aid, the location of the NIF first-aid station, and the location of the On-site Medical Facility as well as where the off-site Occupational Health Clinic is located for construction contractors/subcontractors.

\section{VI.B. Guidelines for Safety Training Meetings}

\section{VI.B.1. Weekly Basis}

The supervisor is responsible for preparing and conducting safety training meetings for employees on a weekly basis. Special safety meetings should be conducted as soon as possible when notified by the Construction Management of serious accident, incident 
or potential problem on-site. Construction contractors/subcontractors will be notified with pertinent information concerning these incidents where a common hazard exists or information is necessitated.

\section{VI.B.2. Essential Element}

These meetings are an essential element of safety and health training. It is a proven fact that projects which conduct good meetings attain better safety records than those that have poor, or no safety meetings.

\section{VI.B.3. Guidelines}

In order to assist in the preparation of material, and in presenting a safety training meeting, the following guidelines are provided.

a. Preparing for the meeting

1. Select the topic for the meeting several days in advance so that you will have a chance to become familiar with the subject to be discussed. You should be able to present the talk in a convincing manner without reading it.

2. Schedule the meeting at the same time every week, if possible, and hold it right in the work area. These meetings are generally 5 to 15 minutes in length so seating is not important. However, make sure everyone can easily see and hear you. A good time to hold the meeting is just after shift begins or immediately following the lunch break.

3. Just prior to the meeting, gather all the material and/or equipment you need. When possible, use actual demonstrations to illustrate your points. For example, if you are talking about fire extinguishers, have one with you to show what it looks like and how it is used. Have a mushroomed tool head or a broken hammer handle to show how they can cause accidents. If necessary, get someone to help you.

4. The entire crew, if possible, should be present before the meeting is started.

5. Safety meeting topics are available from Construction Management.

b. Conducting the meeting

1. Start on time. You may lose employee interest if unnecessary delays occur.

2. Make the meeting short and to the point. However, if you get a good discussion going, use discretion about cutting it off too soon.

3. Start the meeting by complimenting the workers on some recent good work.

4. Give the talk in your own words.

5. Get your people to participate in the meeting. The purpose of these meetings is to get workers to think about safety problems. Encourage them to offer suggestions for improving safety in the work area or your craft.

6. Maintain control. Do not allow the meeting to develop into a wasteful, time consuming "bull session."

c. Other items to cover if applicable 
1. Review any injury or near miss incident any crew member had during the past week or a Special Safety Meeting topic identified by Construction Management. Discuss what the injury was, how it happened, and how it could have been prevented and steps to be taken to prevent reoccurrence.

2. Review safety violations noted during the past week and future avoidances. Discuss the nature of the violation, the danger involved and offer constructive criticism without naming anyone in particular.

3. Review the work planned for the week ahead. Discuss: hazards to avoid or control, safety equipment to be used, and safe procedures to be followed.

\section{VI.B.4. Record Keeping Requirements}

a. Have each employee sign the attendance sheet (Safety Meeting Record, Form $\mathrm{S}+\mathrm{H}$ 6-1) at the conclusion of the meeting and the supervisor conducting the meeting must sign it. A copy of the Attendance Sheet must be forwarded to Construction Management.

b. Make certain it is dated and the crafts attending and the meeting location are listed.

c. Subjects discussed must be covered in detail. "General Safety" is not specific enough.

Section VI.C. Safety Requirements has been deleted. 


\section{NIF Project}

\section{FORM S+H 6-1 SAFETY MEETING RECORD}

LLNL Group/Contractor/Subcontractor

Contract \#

NIF Element

Supervisor

Date

Craft Crew

Subject(s) (Briefly Describe)

Comments

No. of employees on crew

No. in attendance

Attendee Signatures: 


\section{Safety Award Program}

\section{VII.A. Purpose}

Each Conventional Facilities prime subcontractor of NIF will be required to institute a Safety Award Program for its construction workers and subcontractors. The purpose of the Safety Award Program is to recognize and commend those employees and construction subcontractors for their noteworthy achievements in accident prevention.

It must be mentioned that all workers at NIF are expected to assume individual responsibility for performing work safely and for maintaining safety at the NIF construction site. Workers must take a proactive posture for their own safety and their fellow workers.

\section{VII.B. General Qualifications}

Awards are to be made available upon completion of a basic minimum time of employment without a lost time or medically treated injury to have occurred. In addition, an applicant for award must not have been involved in a serious equipment or material damage incident.

Positive reinforcement awards for safe work performance should be distributed by various staff upon observation of work activities.

This program pertains to all employees of the prime construction subcontractor and lower tier subcontractors and their employees directly involved in construction operations. The prime construction subcontractor is to develop an awards program to apply to all workers and lower tier subcontractors performing work on the specific construction package under contract to the prime construction subcontractor.

\section{VII.C. Applications}

Notification should be given that anyone qualifying should notify the Safety Representative of the prime construction subcontractor responsible for the package on which the work was performed. The records will be checked against personal injury and property damage reports and employment records by the prime subcontractor's Safety Representative.

All applications must be signed by the subcontractor's Safety Representative and identified on a Safety Award Application form. Documentation of awards are to be forwarded to the Field Construction Manager for Conventional Facilities and his/her staff for their records. 
Qualified personnel are encouraged to submit applications within a reasonable time following their eligibility. No awards will be made beyond a back date of six months.

\section{VII.D. Award Presentations}

The following outline defines the minimal acceptable award program criteria to be developed by the prime construction subcontractor. Each subcontractor is to tailor their safety program based on the type of work involved in their specific scope of work. The purpose of the program is to provide tangible and social awards to all personnel who complete their work in a safe manner and promote a safe professional approach to how the work is accomplished.

1. Award 1 - To be awarded monthly by the foreman at Tool Box/Tailboard Safety Meeting.

2. Award 2- To be awarded after two consecutive months of safe job performance by the subcontractor's Safety Representative at Tool Box/Tailboard Safety Meeting.

3. Award 3 - To be awarded after three consecutive months of safe job performance.

4. Award 4 - To be awarded after six consecutive months of safe job performance

5. Award 5-To be awarded at completion of project. All employees completing project within criteria are eligible.

6. Award 6-To be awarded to individual employee of a subcontractor on a random basis (weekly) by staff for safe work performance/observation during site walkthrough/safety surveillance activities.

7. Award 7-To be awarded to Subcontractor/Crew for safe work performance for achieving specified goal of no lost time/medical care/equipment damage of special safety achievements.

Award Level

Award 1

Award 2

Award 3

Award 4

Award 5

Award 6

Award 7
Frequency

One (1) Month

Two (2) Months

Three (3) Months

Six (6) Months

Job Completion

Weekly/Daily

Monthly
Award

To be determined

To be determined

To be determined

To be determined

To be determined

To be determined

To be determined 


\section{VII.E. Eligibility}

An employee of the subcontractor should be eligible to receive a maximum of two (2) monthly awards, one (1) two-month, one (1) three-month, one (1) six-month and one (1) job completion award. The random Safe Work Performance Awards are to be determined by the prime construction subcontractor and/or his/her staff.

Form S+H 7-1-Safety Award Application Form has been deleted. 


\section{NIF Project Health \& Safety Plans}

\section{VIII.A. Requirement}

The NIF Construction Management shall ensure that every construction purchase order or subcontract includes the requirement for a Subcontractor "Health \& Safety Plan" submittal. The Health \& Safety plan submittal will be routed to ES\&H Team 2 for review by the cognizant Construction Manager, System Engineer, or NIF Project Office. It is the responsibility of the cognizant Construction Manager or System Engineer to ensure that work does not begin before submittals are reviewed and accepted by both ES\&H Team 2 and the NIF Project Office.

The three NIF Elements (e.g., Conventional Facilities, Special Equipment and Activation and Start-Up) and every construction contractor/subcontractor is required to submit a written NIF specific Health \& Safety Plan. Each lead contractor/subcontractor shall assure that all subcontracted work that they initiate is within the scope of their Health \& Safety plan or that their subcontractor has an appropriate Health \& Safety Plan.

\section{VIII.B. Plan Content}

The written Health \& Safety plan shall inform the reader of the work to be performed and the type of construction safety required for the work. Each NIF Element or subcontractor shall prepare their Health \& Safety plan to conform with OSHA requirements, good safety practices, and the requirements outlined in the CSP for NIF. In addition each subcontractor plan shall conform with the requirements of this document and at a minimum address the applicable safety requirements for NIF constructions activities that are contained in Appendix $A$ of this document. The items identified in Appendix A should not be considered an "all inclusive" list of subjects that should be addressed in an acceptable Health \& Safety Plan for the NIF construction project.

\section{VIII.C. Plan Acceptance}

As required by LLNL policy, the "Health \& Safety" plans of each NIF Element (e.g., Conventional Facilities, Special Equipment and Activation \& Start-Up) and lead Subcontractor has to be reviewed and accepted by the HCD (represented by ES\&H Team 2) before work is allowed to begin. In addition, the NIF Project Office shall also review and approve the plans of the three NIF Elements. The Elements and Subcontractors are encouraged to submit their written plans early to avoid possible delay in beginning their work. 
In addition to "Health \& Safety Plans," certain task specific submittals (e.g., fall protection plans, scaffolding plans, trenching plans, confined space plans, respirator program, etc.) will be required of the subcontractors for HCD. Such submittals must be reviewed and concurred by HCD prior to start of the specific task by the subcontractor. Refer to the topical areas in Appendix A for task specific safety related subcontractor submittals. 


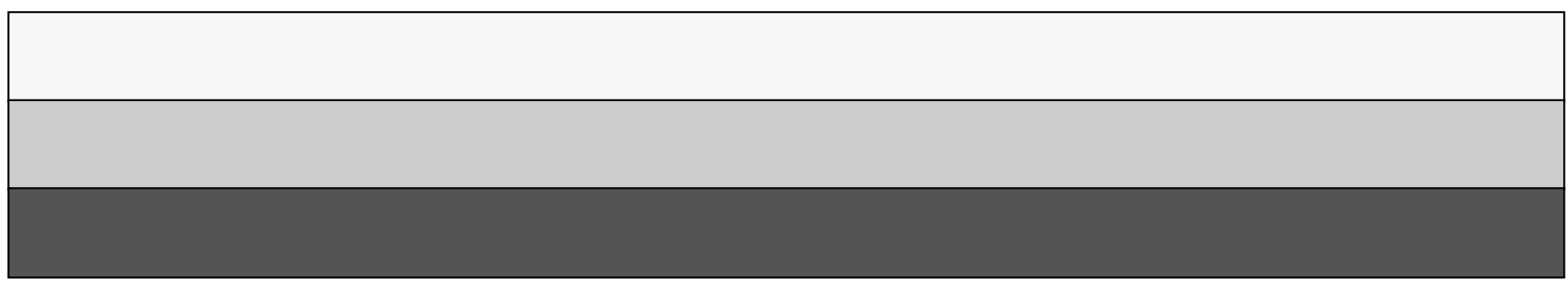

